See discussions, stats, and author profiles for this publication at: https://www.researchgate.net/publication/338018888

\title{
Soil horizon variation: A review
}

Article in Advances in Agronomy · January 2020

CITATIONS

0

8 authors, including:

Alfred E. Hartemink

University of Wisconsin-Madison

308 PUBLICATIONS 4,467 CITATIONS

SEE PROFILE
READS

3

Some of the authors of this publication are also working on these related projects:

Africa Network for Soil Fertility (AfNet) View project 


\title{
Soil horizon variation: A review
}

\author{
A.E. Hartemink ${ }^{a, *}$, Y. Zhang ${ }^{a}$, J.G. Bockheim ${ }^{a}$, N. Curi ${ }^{\text {, }}$, S.H.G. Silva ${ }^{\text {, }}$ \\ J. Grauer-Gray ${ }^{c}$, D.J. Lowe ${ }^{d}$, P. Krasilnikov ${ }^{\mathrm{e}}$ \\ ${ }^{a}$ University of Wisconsin-Madison, Department of Soil Science, FD Hole Soils Lab, Madison, WI, \\ United States \\ ${ }^{\mathrm{b}}$ Federal University of Lavras, Department of Soil Science, Lavras, Brazil \\ 'Illinois Natural History Survey, Champaign, IL, United States \\ ${ }^{\mathrm{d}}$ University of Waikato, School of Science, Hamilton, New Zealand \\ ${ }^{\mathrm{e}}$ Lomonosov Moscow State University, Faculty of Soil Science and Eurasian Center for Food Security, \\ Moscow, Russian Federation \\ *Corresponding author: e-mail address: hartemink@wisc.edu
}

\section{Contents}

1. Introduction

2. Soil profiles and horizons 3

2.1 Soil profiles 3

2.2 Soil variation 4

2.3 Soil horizon formation 6

2.4 Horizon delineation $\quad 12$

3. Soil horizon variation 16

$\begin{array}{ll}3.1 \text { Some early studies } & 16\end{array}$

$\begin{array}{ll}3.2 \text { Within-horizon variation } & 21\end{array}$

3.3 O horizon 24

3.4 A horizon 26

$\begin{array}{ll}3.5 \text { E horizon } & 27\end{array}$

3.6 B horizon 30

3.7 C horizon 31

4. Case studies $\quad 32$

4.1 Spodosols and Histosols-Russia 32

4.2 Alfisol and Mollisol-USA 34

$\begin{array}{ll}4.3 \text { Oxisol-Brazil } & 40\end{array}$

5. Discussion 43

5.1 Within-horizon variation 43

5.2 Horizon boundaries 46

5.3 Implications for soil sampling 48

5.4 Depth functions 49

5.5 Improved soil horizon delineation 50

6. Conclusions 53

Acknowledgments $\quad 54$

References $\quad 54$ 


\section{Abstract}

Soil horizons reflect soil processes and convey information about past and present soil conditions. The identification and delineation of soil horizons are affected by lateral and vertical variation in soil properties. Early studies focused on the variation of horizon thickness and the waviness of horizon boundaries, but did not consider within-horizon lateral and vertical variation. Here we review studies that investigated variation in the master horizons $\mathrm{O}, \mathrm{A}, \mathrm{E}, \mathrm{B}$, and $\mathrm{C}$. We summarize what is known about soil horizon variation, quantify the variation in different horizons, and investigate whether the variation increases or decreases with depth. The variation within horizons differs among soils, and the magnitude of the variation varies for different soil properties. Variation within soil horizons or laterally within a few square meters may be considerable, and the within-horizon variation changes with depth. Horizon thickness does not seem to be related to the variation of soil chemical and physical properties within the horizon, i.e., thicker horizons do not necessarily have higher variation in their soil properties. Three case studies are presented: Spodosols and Histosols (Russia), Alfisol and Mollisol (USA), and Oxisol (Brazil). Factors that affect the within-horizon variations include landscape position, parent material, vegetation, fertilization, tillage, drainage, and time. The vertical distribution of soil properties can be quantified using soil depth functions. Digital soil morphometrics techniques can assist in the quantification of two-dimensional soil profile properties and variations.

\section{Introduction}

Vertical cross-sections of soil profiles are the basic units of morphological studies (Joffe, 1929). The profile contains the history of the soil, with features and the distribution of soil properties encompassed in part by horizon notation, specifying or hinting at past as well as current soil processes (Joffe, 1929; Rice, 1928). Soil profiles are used to study soil formation, soil processes, and soil properties (Churchward, 1961). The profile is also the basic unit of soil classification systems (Soil Classification Working Group, 1998; Soil Survey Staff, 2014).

Soil profiles are divided into layers, called horizons, which are usually parallel to the soil surface (Shaw, 1928; Simonson, 1959). The term horizon is preferable to layer because layers may be associated with geological beds rather than pedogenically-altered materials. Initially, soil horizons were mainly used as a way to describe soils, but over time the soil horizon became a genetic and diagnostic unit. The formation of soil horizons and pedons extending to a depth of ca. 1-2 m, via topdown pedogenesis, follows the initial accumulation or exhumation of a fresh parent material. Alternatively, the ongoing accumulation of a parent material (such as loess or tephra) and its 
transformation into soil horizons concomitantly, rather than sequentially, form the basis of upbuilding pedogenesis. Soil-forming processes and horizonation are modified by the rates at which new materials are added to the land surface via geological processes. The horizonation processes divide a homogenous (isotropic) profile, formed in a uniform parent material, into more heterogeneous (anisotropic) units (Jenny, 1941; Johnson et al., 1987; Knox, 1965).

Soil scientists delineate horizons based on soil properties observed on a profile wall or in a pedon (an exposed three-dimensional soil column) in the field. These properties generally include color, texture, structure, pores, coarse fragments, redoximorphic, and other features. Most field observations of horizon delineation are qualitative, and the number and designation of horizons present as well as the location of the horizon boundaries commonly vary (Arnold and Eswaran, 1993; Schelling, 1970; Weindorf et al., 2012). As Hartemink and Minasny (2014) observed: "In a sense, soil horizons are artificial concepts and in many soils, horizons are irregular, broken, or have nearly invisible boundaries." The increased interest in pedology and the need to study soil profiles using a range of proximal sensing techniques requires improved understanding of the variation in soil horizons and of soil properties. At the same time, proximal sensing technology and image analysis allow for increased quantification of soil horizon variation.

Here we review the variation in soil horizons starting with the concepts of the soil profile and the soil horizon (Section 2) followed by an historical overview of studies that focused on soil horizon variation and a synthesis of what is known about variation of properties for five master soil horizons $(\mathrm{O}$, A, E, B, and C) (Section 3). In Section 4, we present three detailed case studies, and in Section 5 we discuss short-range variation and its implication for soil sampling, horizon delineation, and depth function. The review has the following objectives: (i) to summarize the current knowledge about soil horizon variation; (ii) to investigate whether the variation increases or decreases with depth for different soil properties; and (iii) to quantify the variation of different horizons. The focus of the review is on genetic soil horizon variation as opposed to diagnostic or functional horizon variation.

\section{Soil profiles and horizons}

\subsection{Soil profiles}

The study of soil profiles is essential to the study of soil as a natural body. Although soil profiles were recognized and described before the late 1800s (Hartemink, 2009; Tandarich et al., 2002), the systematic study of soil 
profiles did not occur until soil was recognized as a distinct natural body by F.A. Fallou (Germany), V.V. Dokuchaev (Russia), and E. Hilgard (USA) in the 19th century (Brevik and Hartemink, 2010; Joffe, 1929; Tandarich et al., 2002). Early work on soil horizons was done in Russia by Dokuchaev and his followers. In the USA, some early studies on soil profile features and vertical variations of soil properties were conducted in Michigan by $\mathrm{McCool}$ et al. (1923), and in Wisconsin and North Dakota by Kellogg (1930, 1934). Some soil profile studies were undertaken in New Zealand (e.g., Grange and Taylor, 1932). As Joffe (1929) explained, “....it was the new concept of soils as an independent, natural, historical body which required not only the description of the surface features of soil but also the anatomy of it; for this it is necessary to cut a vertical section and thus obtain a profile view of the exposed vertically dissected body."

Soils are natural bodies that are continuous across the landscape and with depth (Baldwin et al., 1938; Kellogg, 1949; Simonson, 1959). Pedologists divide the soil into discrete units (pedons) for the purposes of sampling, characterization, and classification (Cline, 1944; Marbut, 1921; Smith, 1960). A pedon is a three-dimensional section of the soil body, roughly $1-10 \mathrm{~m}^{2}$ laterally and 1-2-m deep (Smith, 1960; Soil Survey Staff, 1999). The pedon is the smallest division considered representative of the soil (Bockheim et al., 2005; Simonson, 1968). Continuous pedons in the landscape are called polypedons (Soil Survey Staff, 2014). A soil profile is a two-dimensional vertical cross-section of the pedon (Soil Science Division Staff, 2017). The width of a profile can range from a few decimeters to several meters (Soil Science Division Staff, 2017); the depth to which the soil profile is studied is usually restricted to $2 \mathrm{~m}$ although many soils are much deeper. The study of soil profiles is essential to the study of soil as a natural body, for studying soil morphology, soil processes, and soil genesis. The soil profile is also the basic unit of all international and national soil classification systems (IUSS Working Group WRB, 2015; Soil Classification Working Group, 1998; Soil Survey Staff, 2014).

\subsection{Soil variation}

Soils are heterogeneous. The heterogeneity of soils can be inherited (geologically) or acquired (pedologically), or a mixture of both. Soil heterogeneity also is affected by cultivation. A soil can inherit heterogeneity from its parent material (Beckett and Webster, 1971; Robinson and Lloyd, 1915), 
and some is inherited from the presence of multiple parent materials, a heterogeneous parent material, or when new materials are added to the land surface via geological processes (Almond and Tonkin, 1999; Lowe and Tonkin, 2010; Muhs et al., 2004). Such soil formation is referred to as upbuilding pedogenesis, in contrast to topdown pedogenesis (Almond and Tonkin, 1999; McDaniel et al., 2012).

Soil heterogeneity can also result from pedogenic processes. Soil processes transform parent materials into soils that may be more or less heterogeneous than the parent material from which they originated. Soil profile variation reflects the heterogeneity of the parent material as modified by soil processes. A homogeneous parent material such as loess may become more heterogeneous as time progresses, whereas a heterogeneous parent material such as glacial till or layered alluvium may become more homogeneous over time. Soils on stable sites typically become more strongly developed, such as the deepening of an albic (E) horizon and the darkening and thickening of a spodic (Bh, Bs, Bhs) horizon in Spodosols (e.g., Schaetzl and Harris, 2012; Schaetzl and Mokma, 1988). Such increase in heterogeneity was termed pro-anisotropic by Johnson et al. (1987), following the initial usage of these terms by Jenny (1941), or progressive pedogenesis in the dynamic-rate model of soil evolution of Johnson and Watson-Stegner (1987). Some soils become more homogenous (pro-isotropic) through haploidization processes that lead to the destruction of soil horizons (Hole, 1961), for example, by erosion losses or through pedoturbation, which are examples of regressive pedogenesis.

In the past decades, considerable progress has been made in the quantification of soil variation across the landscape. A meta-analysis of soil-forming factors has shown that topography is one of the best predictors of soil conditions (McBratney et al., 2003). For example, in Brazil, four types of Oxisols could be distinguished based on their position in the landscape, and Fe content and soil magnetic susceptibility were used for mapping these soil types (Silva et al., 2016). The systematic variation in soil as a result of topography is often confounded with a random variation which is shortly ranged (within meters) but differs for each soil property (Hartemink et al., 2017). Systematic variation in soil is also sometimes confused with a pattern. Short-range variation in soils has been a source of inconclusive findings, but has resulted in the development of advanced sampling and geostatistical techniques (de Gruijter et al., 2006; Oliver and Webster, 1986, 1991; Webster and Lark, 2012). 


\subsection{Soil horizon formation}

Variation in soil profiles is related to the variation in soil horizons, and the largest changes in a soil profile often occur in a vertical direction (Fig. 1). A large change in the vertical direction can develop a pattern and from that horizons can be identified. In Fig. 1, the profiles 1, 2, and 4 show several horizons based on color differentiation, whereas profile 3 shows only two horizons, a brownish A horizon overlying a reddish brown Bo horizon. Soil scientists generally divide the soil profile into layers called horizons. A horizon is defined in Soil Taxonomy as "a layer, approximately parallel to the surface of the soil that is distinguishable from adjacent layers by a distinctive set of properties produced by the soil-forming processes" (Soil Science Division Staff, 2017). Soil horizonation is an essential soil characteristic (Jenny, 1941; Joffe, 1929; Marbut, 1921), although early on it was recognized that some soil profiles lack discernible horizons or layers (Marbut, 1928; Shaw, 1928).

All factors of soil formation (climate, organisms, relief, parent material, and time) affect soil horizon formation. Horizons may be the resultant of parent material and are formed by the interaction of soil processes (Hole, 1961; Johnson et al., 1987; McBratney, 1993). According to Simonson (1959), in a broad sense, soil-forming processes consist of gains, losses, translocation, and transformation of mineral and organic materials in a soil profile. All these processes affect soil horizonation. Fig. 2 illustrates how soil horizon thickness changes across the landscape, over time, and with different land use
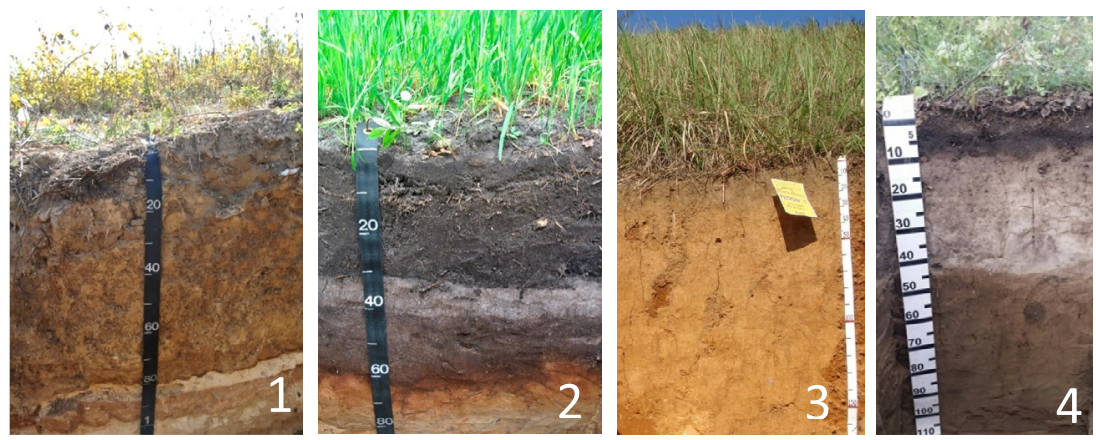

Fig. 1 Variations in horizons of soil profiles: 1. Hapludalfs developed in loess over colluvium from Wisconsin, USA; 2. Cultivated Spodosol from Overijssel, Netherlands; 3. Paleudults from Rio Grande do Sul, Brazil; 4. Natric Argiorthels from Sakha (Yakutia) (eastern Siberia). Measuring tapes in centimeters. 


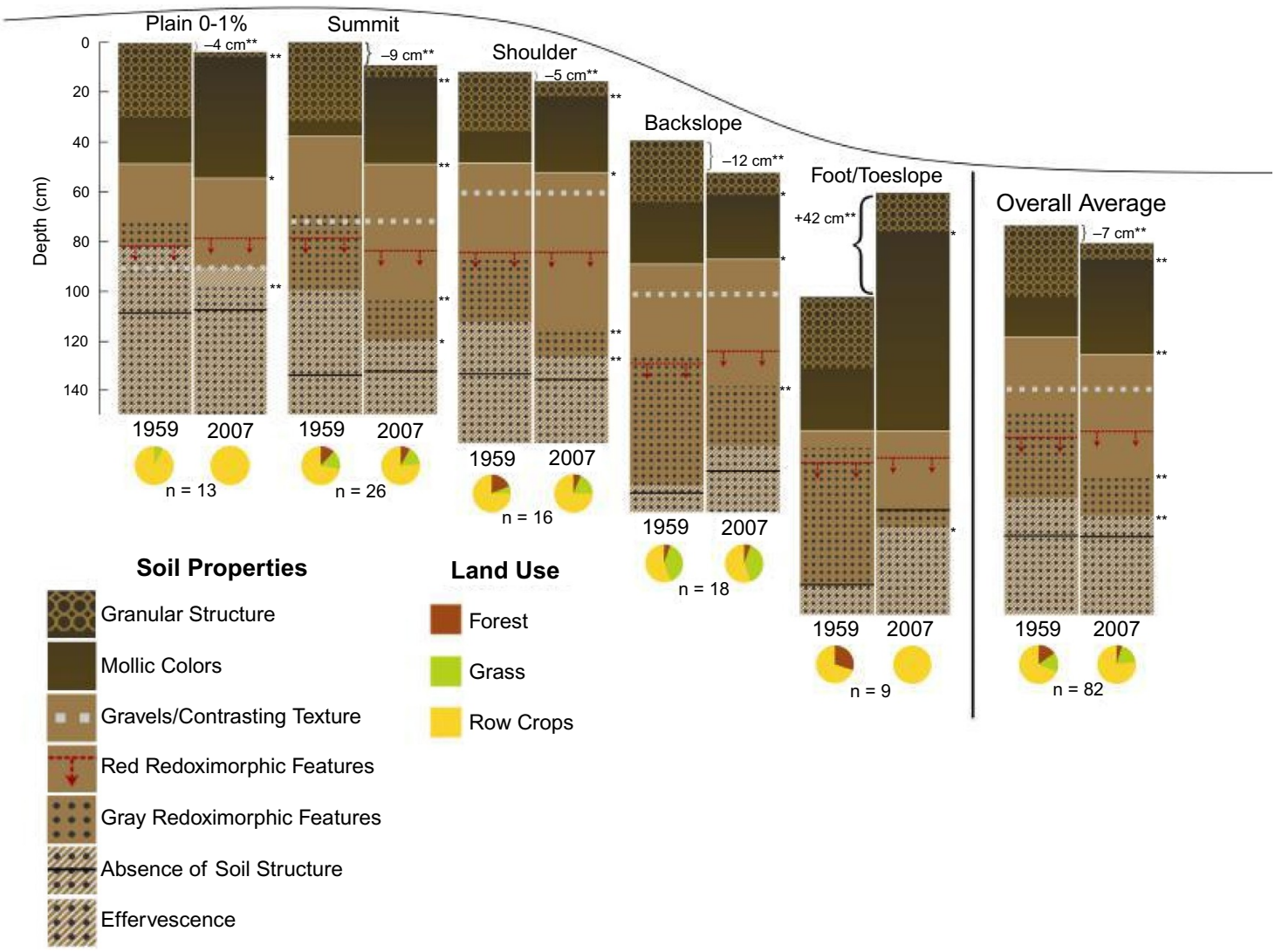

Fig. 2 Soil profile changes across the landscape, over time, and with different land use (Veenstra and Lee Burras, 2015). 
(Veenstra and Lee Burras, 2015). This figure shows that all three factors play an important role in soil horizonation.

Soil processes such as illuviation and eluviation represent gains and losses, respectively, and promote the formation of horizons; in contrast, processes such as pedoturbation can disrupt the formation of horizons (Hole, 1961; Johnson et al., 1987, 1990). Horizonation processes produce soil anisotropy, differentiating the soil into often, but not always, approximately horizontal layers, thus increasing the number of horizons (Fig. 3). Haploidization processes promote isotropy, causing the various parts of the soil to become more similar and reducing the number of horizons in a soil profile (Fig. 3). Haploidization can blur horizon boundaries, mix horizons, and it may result in remnants of the horizons remaining as broken horizons. All soils have horizonation and haploidization processes occurring within them.
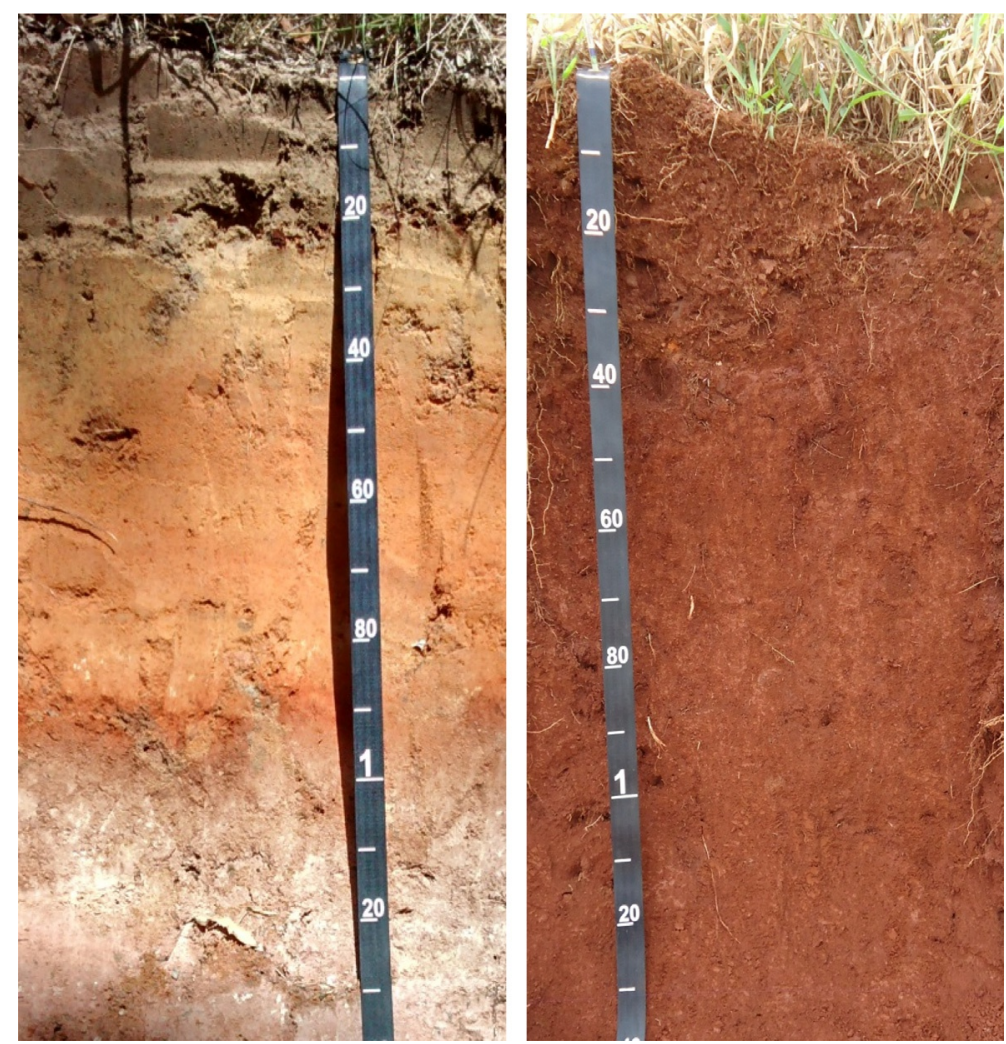

Fig. 3 Soil profiles representing horizonation (left) and haploidization (right) in two Ultisols from Brazil. Measuring tapes in centimeters. 

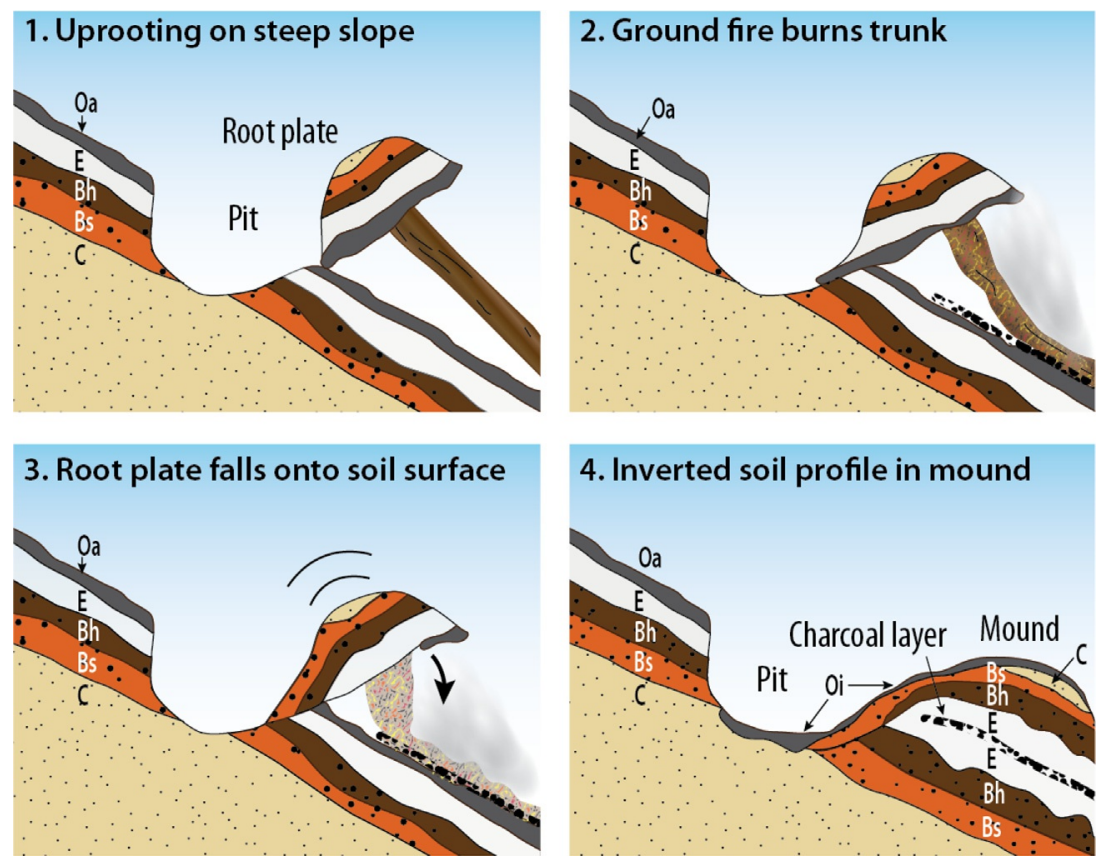

Fig. 4 Depiction of profile inversion of a Spodosol on a slope by tree overturn, USA. Redrawn from Schaetzl, R.J., Follmer, L.R., 1990. Longevity of treethrow microtopography: implications for mass wasting. Geomorphology 3, 113-123, following Schaetzl, R.J., 1986. Complete soil profile inversion by tree uprooting. Phys. Geogr. 7, 181-189. Reproduced with permission.

Soil constituents may also be translocated within a profile, such as by extreme threshold-controlled leaching (Stoner and Ugolini, 1988), and entire profiles can be inverted by tree overturn (Fig. 4). For example, in Fig. 5, tree overturn hollows and mounds are evident on the buried paleosol surface. Soil profiles thus record the history of the soil, including geological processes (e.g., deposition or accumulation) as well as pedogenic processes (Johnson et al., 1990; Schaetzl and Follmer, 1990; Schelling, 1970). Differences in soil texture inherited from parent material, or resulting from soil processes may enhance soil horizon formation. Boundaries between areas of different textures or structures affect soil-water movement and soil processes. Changes in soil texture may also affect biota and thus soil processes. Similarly, the change in the availability of nutrients for biota affects plant and microbe growth and thus soil processes.

Modern soil taxonomic systems identify anthropogenic (human caused) soil horizons, such as the plaggen epipedon and the agric horizon, and those 


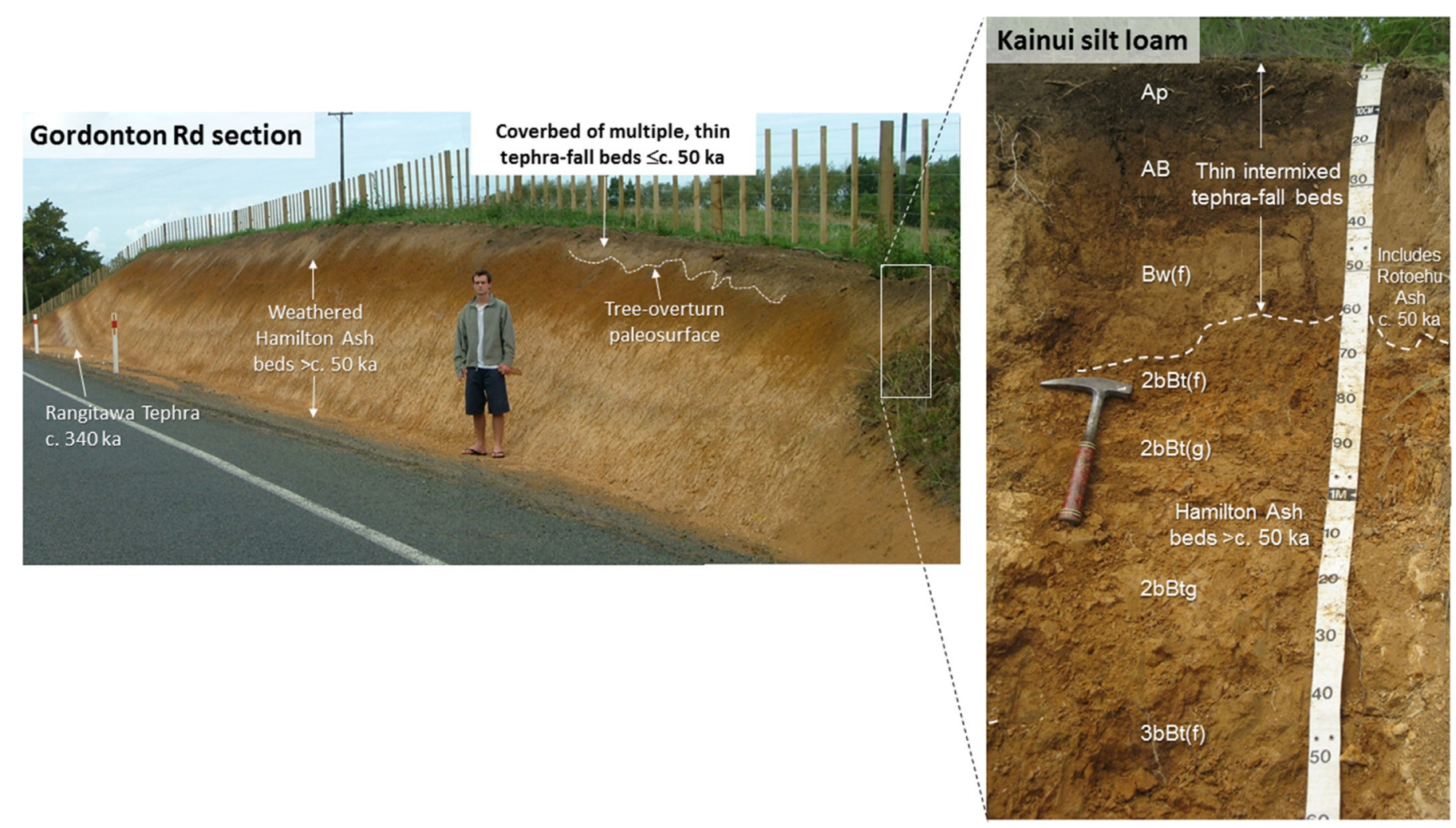

Fig. 5 Weathered tephras and soil horizons exposed in a road cut near Hamilton, New Zealand. Thin tephras accumulated millimeter-bymillimeter so that soils and buried paleosols formed through developmental upbuilding pedogenesis (Lowe, 2019). Redoximorphic features in the Bw(f) horizon indicate perching on the buried paleosurface marked by the $2 \mathrm{bBt}(\mathrm{f})$ horizon. The soil is a Kainui silt loam or Typic Kandiudults. Horizon nomenclature follows Clayden and Hewitt (1989); the prefix "b" denotes a soil horizon with pedogenic features developed before its burial. $\mathrm{ka}=$ thousands of years ago. Photos by D.J. Lowe (section) and R. McEwan (profile) (modified after Lowe, D.J., 2019. Using soil stratigraphy and tephrochronology to understand the origin, age, and classification of a unique Late Quaternary tephra-derived Ultisol in Aotearoa New Zealand. Quaternary 2, 1-34). 


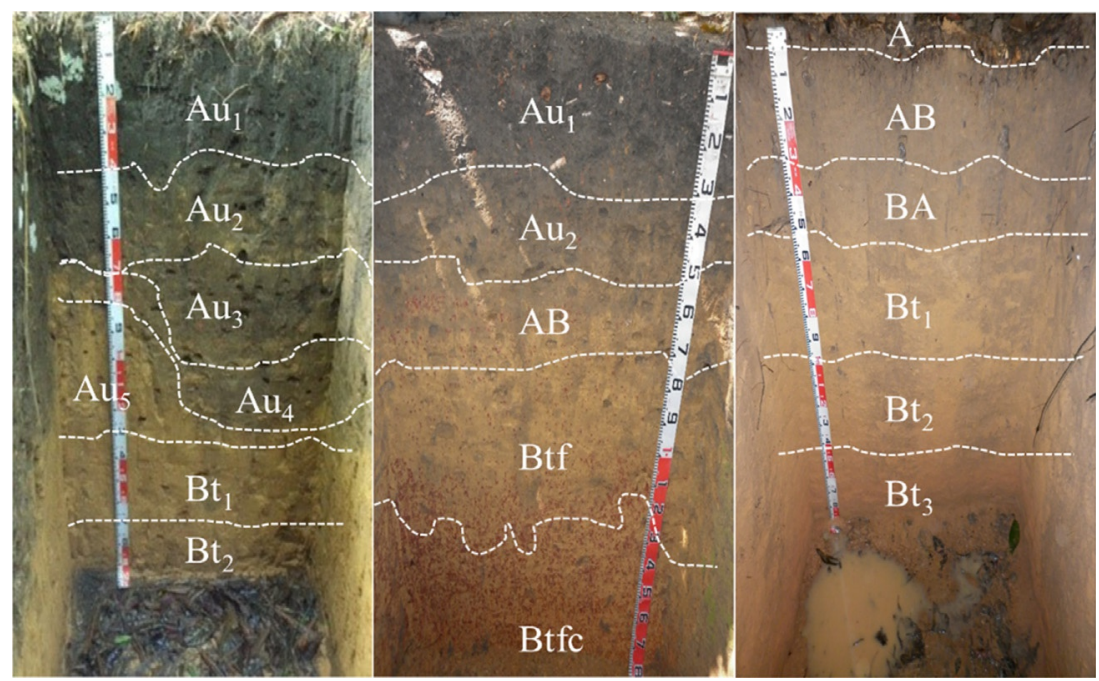

Fig. 6 Three Anthrosols (Amazonian Dark Earth, Terra preta) from Brazil. Soil horizon formation was affected by cumulization, bioturbation, melanization, argilluviation, and degradation of iron nodules. Horizon designation following the Brazilian classification system: $\mathrm{Au}=\mathrm{A}$ horizon with anthropogenic alterations; $\mathrm{Bt}=\mathrm{B}$ horizon with clay accumulation; $\mathrm{Btf}=\mathrm{B}$ horizon with clay accumulation and lateritic materials or plinthite; $\mathrm{Btf} C=\mathrm{B}$ horizon with clay accumulation, lateritic materials or plinthite and concretions or hard materials (Macedo et al., 2017).

developed in constructional landforms. Soil horizons are affected by human activities that may enhance clay dispersion and argilluviation (Macedo et al., 2017). The Anthrosols in Fig. 6 were affected by the addition of organic residues and ceramic artifacts (cumulization); the use of fire; mechanical action of humans, roots, and macrofauna (bioturbation); melanization of deeper horizons as a result of bioturbation; argilluviation; and degradation of iron nodules (Macedo et al., 2017). Another example is the conversion of an allophanic to non-allophanic Andisol mineralogy associated with the establishment of bracken in northern Idaho (Johnson-Maynard et al., 1997). The consequent changes included increased soil carbon, darker soil color, lower $\mathrm{pH}$, and increased organic forms of active Al. In New Zealand, the application of fertilizer containing fluorine resulted in increased rates of chemical weathering of parent materials (predominantly volcanic glass) within less than a century (Taylor et al., 2016).

Diagnostic soil horizons, as opposed to genetic soil horizons, are used (along with control sections) as criteria for soil classification in Soil Taxonomy and WRB (IUSS Working Group WRB, 2015; Soil Survey 
Staff, 2014). For example, in Soil Taxonomy, Mollisols must have mollic epipedons (Soil Survey Staff, 1999). Bockheim and Gennadiyev (2000) found that the diagnostic horizons and epipedons defined in Soil Taxonomy and WRB can be linked to major soil processes, which in turn relate to soilforming factors (Bockheim, 2018). For example, histic horizons form due to the process of paludization (Bockheim and Gennadiyev, 2000), andic soil properties arise through the process of andisolization (Dahlgren et al., 2004; Duchaufour, 1977; McDaniel et al., 2012), and spodic horizons form through the process of podzolization (Ugolini et al., 1988).

\subsection{Horizon delineation}

Soil profiles are divided into soil horizons to classify and increase our understanding and characterization of soils. Ramenskiy (1938) proposed that soil descriptions show vertical distribution of continuous individual properties without separating the profile into discrete zones. However, this approach was not used until recently (Minasny et al., 2016). Kornblum (1975) developed a hierarchical system of soil morphology: at the first level, simple or complex morphemes were identified, whereas on the second level, morphons constituted a soil profile. Morphons could be horizons, parts of horizons or closed formations of irregular shape. He also described some profiles that had a mosaic structure without clear soil horizons (Kornblum, 1975).

Horizon designations provide a shorthand way of recording and communicating soil profile observations (Bridges, 1993; Papadakis, 1964). Horizon designations have changed over time in different soil classification systems (Gerasimova et al., 2013). In Soil Taxonomy and WRB, three types of symbols are used: capital letters, lower case letters, and Arabic numerals. The capital letter is used to designate the master horizon whereas the lower case horizon suffixes communicate observations such as silicate clay accumulation (IUSS Working Group WRB, 2015; Soil Survey Staff, 2014). Arabic numerals are used as suffixes to indicate vertical subdivisions within a horizon or layer and as prefixes to indicate lithological discontinuities (Figs. 5 and 7).

Horizons can have many shapes but are usually defined as roughly parallel to the soil surface (Bockheim et al., 2005; Soil Classification Working Group, 1998; Soil Survey Staff, 1999). Horizon differentiation is a learned skill, "a product of soil science training and/or experience" (Churchman, 2010). In fact, it might be regarded as the most important part of a soil profile 

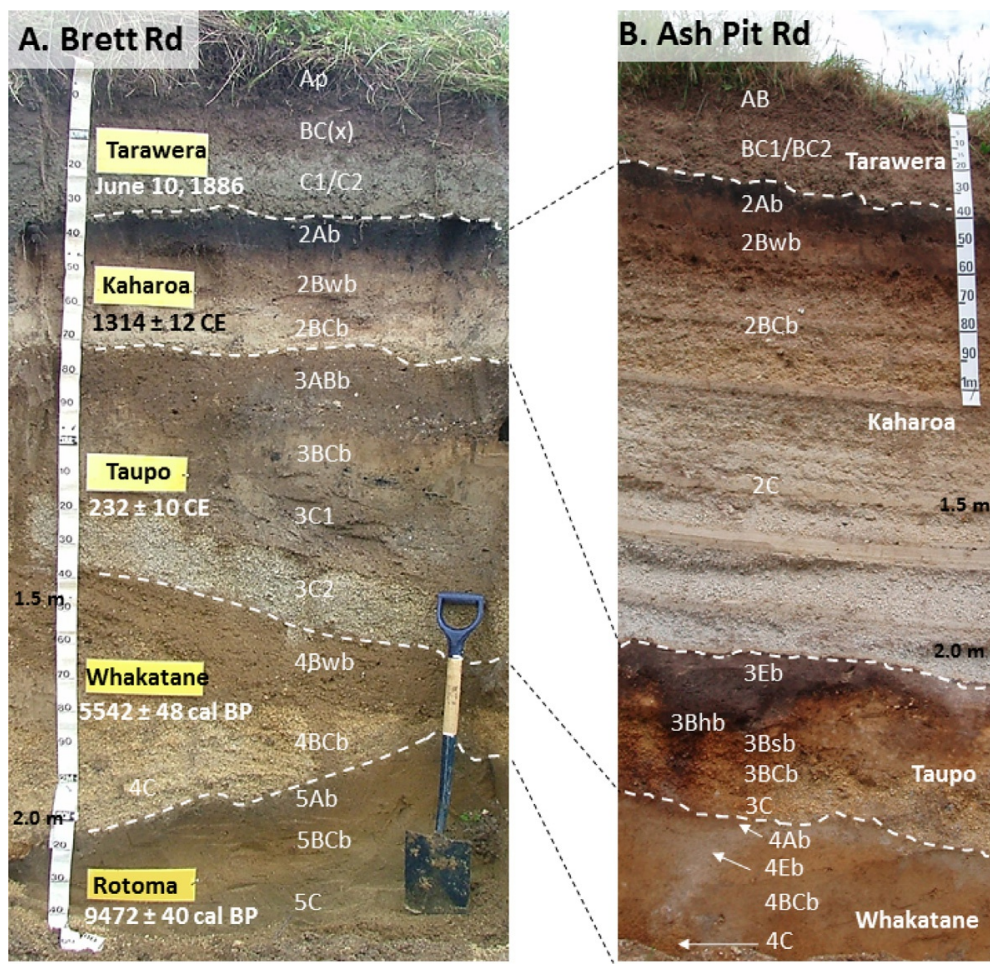

Fig. 7 Multi-layered tephra-derived soils formed through upbuilding pedogenesis near Mt Tarawera, New Zealand. (A) This soil is a Typic Udivitrands. The names and dates/ages refer to separate tephra-fall events during the Holocene. (B) This soil is a Vitrandic Udorthents; buried spodic and albic materials are evident below $2 \mathrm{~m}$. Horizon nomenclature follows Soil Survey Staff (2014). Photos by R. McEwan and H.S. Jones.

description. The genetic relationships of soil horizons are important for an understanding of pedogenesis and soil management. Soil scientists are trained to primarily look along a vertical transect for horizons that parallel the soil surface (Muir, 1962), and thus most soil scientists preferentially identify and describe regions parallel to the soil surface. Horizons are usually delineated based on soil properties observed in the field. Soil horizons are usually more homogeneous regarding at least one soil property than the soil profile as a whole. However, some horizons are heterogeneous by definition. For example, the glossic horizon defined in Soil Taxonomy must contain both eluvial and illuvial material (Soil Survey Staff, 2014). 
Combination (composite) horizons contain discrete areas of multiple horizons (FitzPatrick, 1993; Soil Survey Staff, 2014). Horizons that are homogeneous with respect to one property are not necessarily homogeneous with respect to other properties. As Cline (1944) pointed out, "Physical homogeneity vertically does not ensure chemical homogeneity." Dmitriev (1983) stressed that "one should not expect that the horizons will be homogeneous (in any sense of homogeneity) in other scales of measurements of the same characteristics, and even more so on the base of properties that were not taken into account when allocating the horizon." In other words, physical, chemical, or mineralogical homogeneity of a single property or even multiple properties does not ensure homogeneity of the soil properties not used for horizon delineation.

Some field observations are qualitative, and the number of horizons present as well as the location of the horizon boundaries may vary (Arnold and Eswaran, 1993; Schelling, 1970; Weindorf et al., 2012). The process of horizon delineation may include some subjective judgments (Boone et al., 1999; Hartemink and Minasny, 2014). Boone et al. (1999) noted that differences in horizon delineations may result from "a 'lumper' versus 'splitter' approach to description and sampling." Some soil scientists, the splitters, tend to differentiate horizons based on small changes in properties such as color, texture, and structure, whereas other soil scientists, the lumpers, differentiate horizons only if they consider the changes in at least one property to be large. It is also possible that discontinuous or thin horizons may be overlooked in horizon delineation or sampling (Boone et al., 1999). Discontinuous soil horizons represent a challenge for morphological description, because a limit should be established between a fragmented horizon and simple inclusions of a morphologically different material. Dmitriev (1983) defined five types of horizon continuity: continuous, discontinuous, fragmented, sporadic, and absent. These correspond generally to classes of topography of soil horizon lower boundaries in Soil Taxonomy: smooth, wavy, irregular, and broken. If the horizon is continuous in one part of the profile and absent in another part, there are probably two different soil taxonomic units.

The ability to assess soil horizon boundaries as well as the variation within a horizon depends on the observational method. Soil horizons can be observed in a soil pit, or using a soil auger or push probe. Soil horizons can also be observed in road cuts and in quarries provided they are fresh and not overgrown (Fig. 8). In soil pits, soil horizons can be delineated easily, 

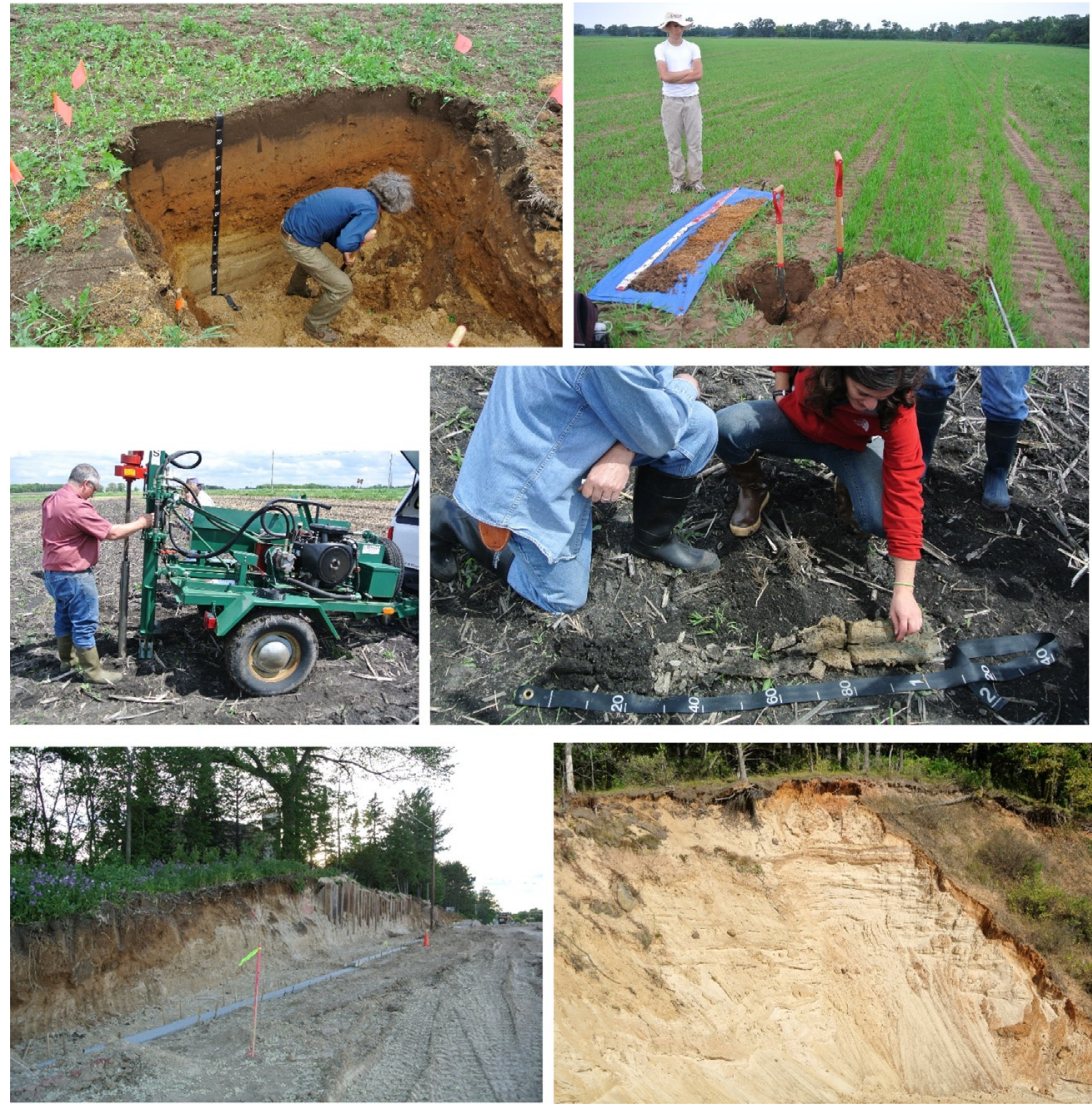

Fig. 8 Soil horizons can be observed in a soil pit, soil augerings, using a push probe or observing soils along road cuts and in quarries.

whereas road cuts and quarries may allow for observations on horizontal variation across a larger distance (Table 1). Freshly dug drains may be useful if not filled with water. The examination of a soil profile along only one vertical transect characterizes the soil profile only at the location of that transect. Horizontal variation of soil profiles and soil horizons can occur within short distances. Phillips (1993) observed representatives of four soil series in a 1.8m-wide soil pit. Even in soil profiles containing less variation, soil scientists characterizing a profile along one transect may overlook broken horizons or incorrectly identify a combination of horizons as homogeneous, especially if changes in color are absent or minimal. 
Table 1 Assessment of soil horizon boundaries and soil horizon purity based on different observation methods.

\begin{tabular}{|c|c|c|c|c|}
\hline Observation & $\begin{array}{l}\text { Soil horizon } \\
\text { delineation }\end{array}$ & $\begin{array}{l}\text { Soil } \\
\text { horizon } \\
\text { purity }\end{array}$ & $\begin{array}{l}\text { Horizontal } \\
\text { variation }\end{array}$ & Limitations \\
\hline Soil pit & +++ & +++ & ++ & $\begin{array}{l}\text { Not possible everywhere, } \\
\text { destructive, may need a } \\
\text { backhoe }\end{array}$ \\
\hline $\begin{array}{l}\text { Auger hole } \\
\text { observation }\end{array}$ & + & + & - & Mixing of horizons \\
\hline Push probe & + & ++ & - & $\begin{array}{l}\text { Small horizontal volume, } \\
\text { requires truck for hydraulics }\end{array}$ \\
\hline Slice shovel & ++ & + & - & $\begin{array}{l}\text { Mostly topsoil, limited soil } \\
\text { depth }(<0.5 \mathrm{~m})\end{array}$ \\
\hline Roadcuts & ++ & ++ & +++ & $\begin{array}{l}\text { Sometimes disturbed, } \\
\text { overgrown, may not be fresh }\end{array}$ \\
\hline Quarries & + & ++ & +++ & $\begin{array}{l}\text { Difficult to sample or make } \\
\text { detailed observations }\end{array}$ \\
\hline
\end{tabular}

+++ well suited; ++ suitable; + possible but not accurate; - not suited.

\section{Soil horizon variation}

\subsection{Some early studies}

The existence of short-range lateral variation of soil properties has been recognized since the early 1900s. Alway and Trumbull (1912) found that the differences in total $\mathrm{N}$ and humus in the surface soils $(0-30 \mathrm{~cm}$ depth) of prairies between samples $5 \mathrm{~cm}$ apart could be as high as the differences in those properties between prairie soils and cultivated soils. Waynick (1918) showed that the lateral variation of residual nitrate in the topsoil $(2.5-15 \mathrm{~cm}$ depth) occurring within $3 \mathrm{~m}$ in a field was more than half that measured in the entire field $\left(730 \mathrm{~m}^{2}\right)$. Waynick and Sharp (1919) found that the lateral variation within $3 \mathrm{~m}$ of soil organic matter $(\mathrm{SOM})$ and total nitrogen at $0-30 \mathrm{~cm}$ depth was generally a third to a half of the total variation in a 0.5 ha field. Within a single soil aggregate (diameter $\approx 15 \mathrm{~cm}$ ), Purvis and Davidson (1948) found a considerable variation of soil $\mathrm{pH}$ (ranging from 6.0 to 7.1) (Fig. 9). These early studies are notable for their investigation of short-range lateral variation, but they did not explicitly investigate soil horizon variation. With the exception of Purvis and Davidson (1948), these studies predated the widespread acceptance of the concept of soil horizons (Simonson, 1962). 


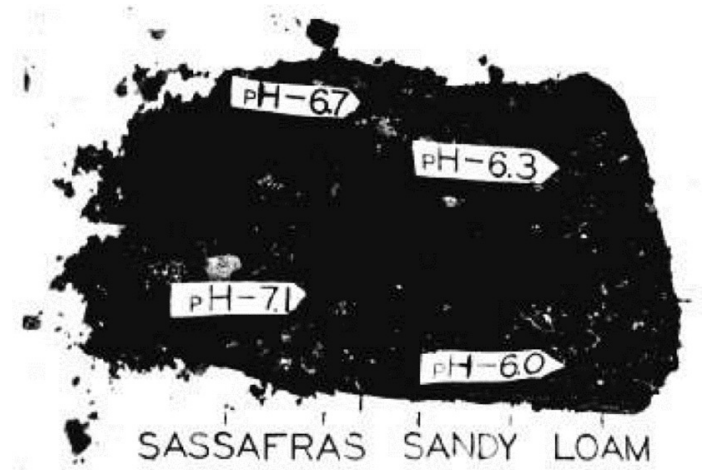

Fig. 9 Variation of $\mathrm{pH}$ within a single soil aggregate with a diameter of approximately $15 \mathrm{~cm}$ (Purvis and Davidson, 1948).

The study of horizon variation started in the 1920s with the acceptance and global dissemination of the concepts of the soil profile and soil horizon. It was accelerated in part by the translation of K.D. Glinka's textbooks from German into English for the First International Congress of Soil Science in 1927. Table 2 provides a timeline of selected soil horizon variation studies. A few studies (e.g., Kellogg, 1934; Lyford, 1939) used scaled profile drawings or photography to show the irregularity and variability of soil horizons (Fig. 10). These studies focused on the variation of horizon thickness and the waviness of horizon boundaries but did not measure within-horizon variation.

Several studies collected multiple samples within each horizon and quantified the within-horizon variation with the coefficient of variation $(\mathrm{CV})$, defined as the standard deviation divided by the mean and generally expressed as a percentage. One of the first studies quantifying soil horizon variation studied Spodosols and Mollisol and found that the Spodosols had considerably more microvariation than Mollisol (Vazhenin et al., 1969). They also found greater variation in the topsoil than in the subsoil, and that the vertical variation was roughly equal to the horizontal variation in the corresponding horizons. Drees and Wilding (1973) studied elemental variation in three Alfisols and found that the variation increased in the sequence of loess-till-outwash. No differences in variations between A, B, and C horizons were observed. Patterson and Wall (1982) collected replicate samples from A, B, and C horizons of 41 pedons (Alfisols and Mollisols) for the investigation of within-pedon variability and found the greatest variation in B horizons and lowest variation in A horizons. Göttlein and Matzner (1997) investigated microscale variation with a grid sampling scheme $(10 \times 6$ grid with $2-\mathrm{cm}$ interval $)$ of the acid-related stress-parameters ( $\mathrm{Al}, \mathrm{Ca}$, and $\mathrm{pH}$ ) in a forested Spodosol, and found 
Table 2 Timeline of some selected soil horizon variation studies.

\section{Depths Area}

\begin{tabular}{|c|c|c|c|c|c|c|c|c|c|}
\hline Year & Soil order & Horizons & $(\mathrm{cm})$ & $\left(m^{2}\right)$ & Properties & Land use & profiles & Location & Reference \\
\hline 1932 & Spodosol & $\begin{array}{l}\text { A, E, } \\
\text { BA, Bs, } \\
\text { BC, C }\end{array}$ & $0-100$ & - & $\begin{array}{l}\text { Horizon description, } \\
\text { thickness }\end{array}$ & $\begin{array}{l}\text { Native forest or } \\
\text { pasture after } \\
\text { cleared native } \\
\text { forest }\end{array}$ & 4 & $\begin{array}{l}\text { New } \\
\text { Zealand } \\
\text { (North } \\
\text { Island) }\end{array}$ & $\begin{array}{l}\text { Grange and Taylor } \\
(1932)\end{array}$ \\
\hline 1934 & Alfisol & $\mathrm{A}, \mathrm{B}, \mathrm{C}$ & $\begin{array}{l}0-7.6 \\
\text { to } 0-76\end{array}$ & - & Horizon description & Prairie & 11 & $\begin{array}{l}\text { USA } \\
\text { (ND) }\end{array}$ & Kellogg (1934) \\
\hline 1939 & Spodosol & $\begin{array}{l}\mathrm{O}, \mathrm{A} \\
\mathrm{B}, \mathrm{C}\end{array}$ & $0-150$ & 11.6 & Horizon description & Road cut & 3 & $\begin{array}{l}\text { USA } \\
(\mathrm{NH})\end{array}$ & Lyford (1939) \\
\hline 1973 & Alfisol & $\mathrm{A}, \mathrm{B}, \mathrm{C}$ & $\begin{array}{l}0-353 \\
0-211 \\
0-249\end{array}$ & $\begin{array}{l}5,3 \\
3.6\end{array}$ & Elements & - & 3 & $\begin{array}{l}\text { USA } \\
(\mathrm{OH})\end{array}$ & $\begin{array}{l}\text { Drees and Wilding } \\
\text { (1973) }\end{array}$ \\
\hline 1980 & $\begin{array}{l}\text { Alfisol, } \\
\text { Mollisol }\end{array}$ & $\begin{array}{l}\text { Whole } \\
\text { pedon }\end{array}$ & - & 1 & $\begin{array}{l}\text { Texture, bulk density, } \\
\text { elements }\end{array}$ & Agriculture & 5 & $\begin{array}{l}\text { USA } \\
(\mathrm{OH})\end{array}$ & $\begin{array}{l}\text { Smeck and Wilding } \\
(1980)\end{array}$ \\
\hline 1981 & Alfisol & $\begin{array}{l}\text { Whole } \\
\text { pedon }\end{array}$ & $\begin{array}{l}0-540 \\
0-410\end{array}$ & 10 & $\begin{array}{l}\text { Bulk density, real density, } \\
\text { texture, hardness, specific } \\
\text { surface area }\end{array}$ & Spruce forest & 2 & Russia & Dmitriev et al. (1981) \\
\hline
\end{tabular}




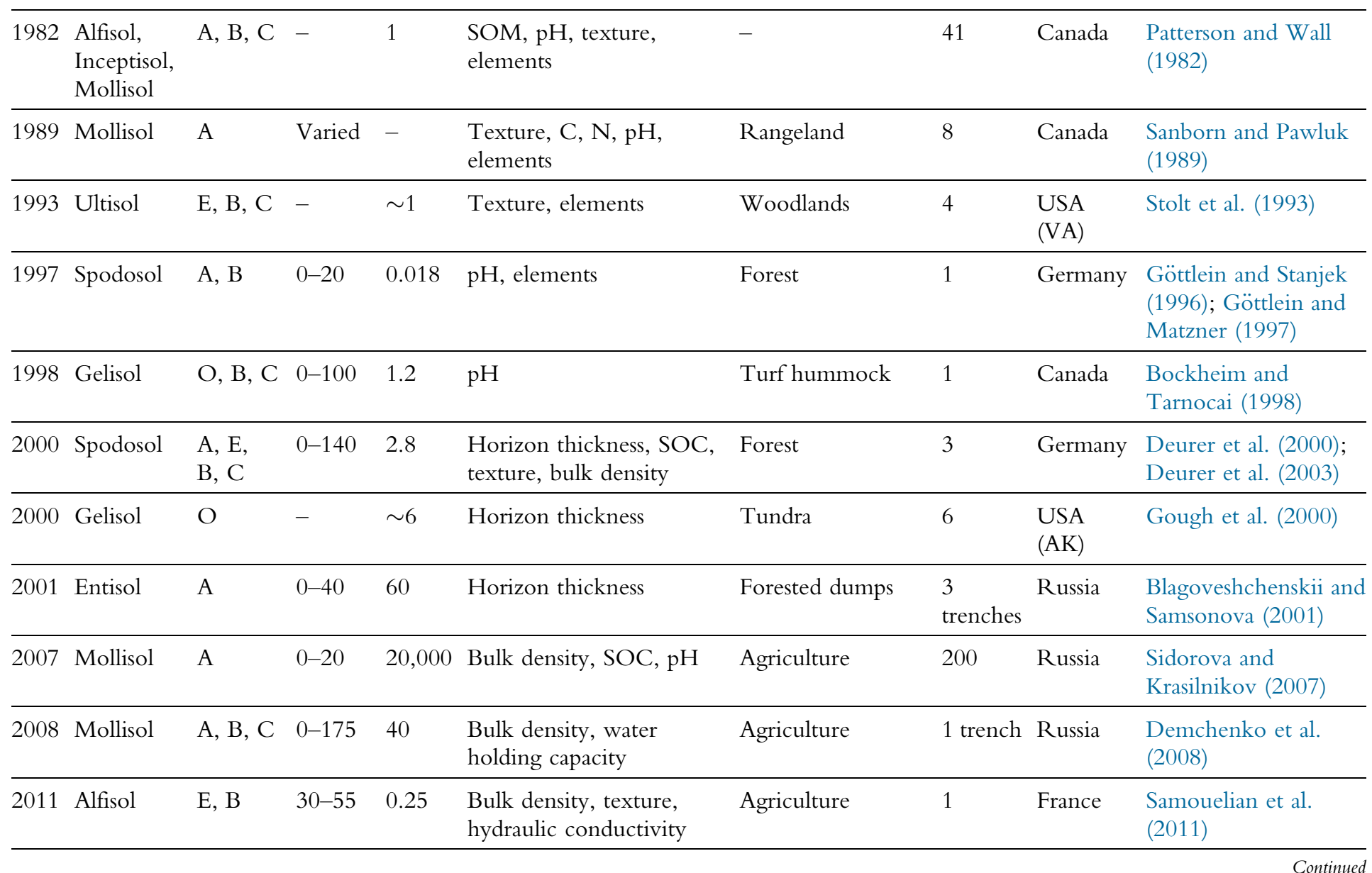


Table 2 Timeline of some selected soil horizon variation studies_cont'd

\begin{tabular}{|c|c|c|c|c|c|c|c|c|c|}
\hline Year & Soil order & Horizons & $\begin{array}{l}\text { Depths } \\
\text { (cm) }\end{array}$ & $\begin{array}{l}\text { Area } \\
\left(\mathrm{m}^{2}\right)\end{array}$ & Properties & Land use & $\begin{array}{l}\text { \# of } \\
\text { profiles }\end{array}$ & Location & Reference \\
\hline 2013 & Gelisol & $\begin{array}{l}\mathrm{O}, \mathrm{A} \\
\mathrm{B}, \mathrm{C}\end{array}$ & $0-100$ & $\begin{array}{l}1.2 \\
1.6,3\end{array}$ & Horizon description & Tundra & 4 & $\begin{array}{l}\text { USA } \\
(\mathrm{AK})\end{array}$ & $\begin{array}{l}\text { Ping et al. (2013); } \\
\text { Bockheim et al. (1999, } \\
\text { 2004); Bockheim } \\
\text { (2007) }\end{array}$ \\
\hline 2015 & Entisol & $\mathrm{A}, \mathrm{C}$ & $0-20$ & 62,500 & $\begin{array}{l}\text { SOC, } \mathrm{pH} \text {, water extract } \\
\text { composition }\end{array}$ & Salt marsh & 123 & Russia & Sidorova et al. (2015) \\
\hline 2016 & $\begin{array}{l}\text { Histosol, } \\
\text { Spodosol }\end{array}$ & $\mathrm{O}, \mathrm{A}$ & $0-20$ & 10,000 & SOC, $\mathrm{pH}$ & Agriculture & 100 & Russia & Sidorova (2016) \\
\hline 2017 & $\begin{array}{l}\text { Alfisol, } \\
\text { Mollisol }\end{array}$ & A, B & $0-100$ & 1.0 & Horizons, SOC & Agriculture & 2 & $\begin{array}{l}\text { USA } \\
\text { (WI) }\end{array}$ & $\begin{array}{l}\text { Zhang and Hartemink } \\
\text { (2017) }\end{array}$ \\
\hline 2018 & $\begin{array}{l}\text { Alfisol, } \\
\text { Entisol, } \\
\text { Mollisol }\end{array}$ & A, B & $0-100$ & $\begin{array}{l}1.0 \\
0.6\end{array}$ & $\begin{array}{l}\text { Horizon description, } \\
\text { SOC, } \mathrm{pH} \text {, elements }\end{array}$ & Agriculture & 3 & $\begin{array}{l}\text { USA } \\
\text { (WI) }\end{array}$ & $\begin{array}{l}\text { Grauer-Gray and } \\
\text { Hartemink (2018) }\end{array}$ \\
\hline
\end{tabular}



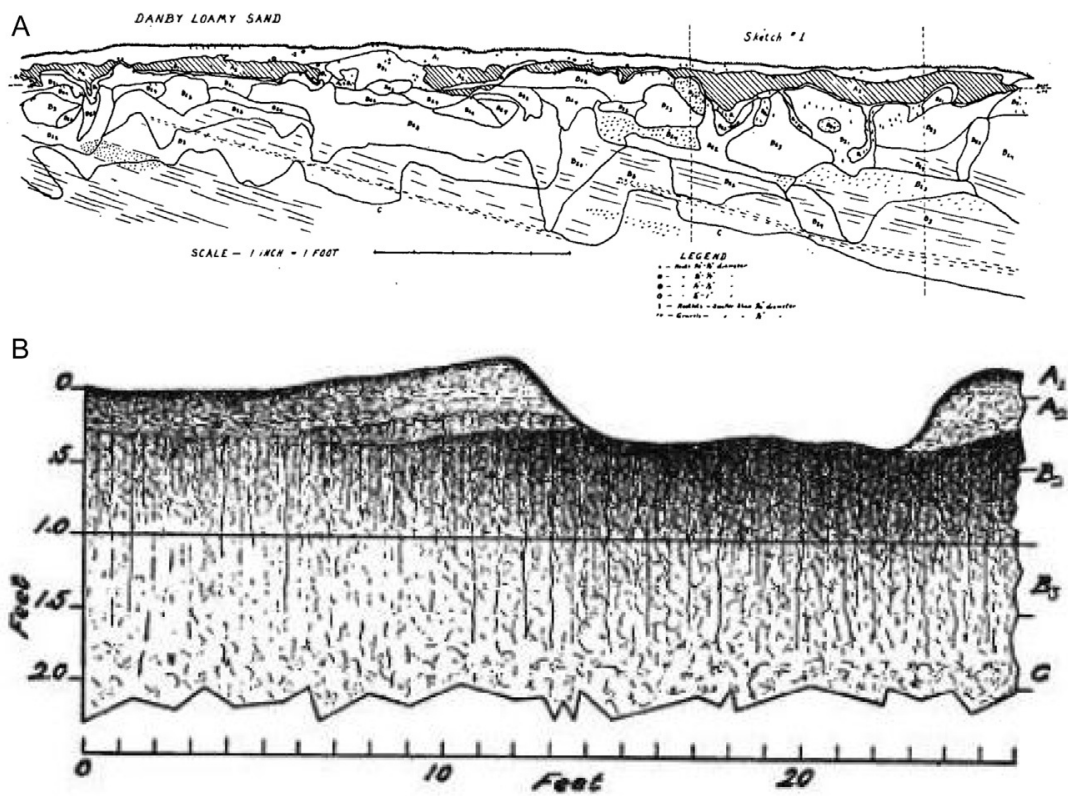

Fig. 10 Variation of soil horizon thickness and boundaries in (A) Spodosol (Danby loamy sand) profile over a lateral distance of approximately $7.6 \mathrm{~m}$ (Lyford, 1939). Vertical scale is the same as horizontal scale; and (B) an eroded solodized Solonetz (sodium-rich Alfisol) occurring in a brown soil developed from glacial till (Kellogg, 1934).

that microscale heterogeneity is essential for investigating the chemical environment for root growth and plant nutrition. Deurer et al. (2000) used grid sampling with a spacing of $15 \mathrm{~cm}$ to study the variation of water characteristic functions in Spodosols under pine forest and found that the distribution of SOC was important for heterogeneity of water characteristics in the profiles.

\subsection{Within-horizon variation}

In the following sections, we review each of the master horizons $(\mathrm{O}, \mathrm{A}, \mathrm{E}, \mathrm{B}$, and $\mathrm{C}$ ) and discuss variation in soil properties. Most studies have focused on chemical soil properties and soil texture, and we were unable to find studies on variation of redoximorphic features or soil structure. Table 3 shows that most studies on soil horizon variation have been conducted in Alfisols and Spodosols, and a few studies have been conducted on Entisols, Gelisols, Histosols, Inceptisols, Mollisols, Oxisols, Ultisols, and Vertisols. More studies have focused on variation in the $\mathrm{A}$ and $\mathrm{B}$ horizons than on the other horizons. Variation in soil organic carbon, texture, and $\mathrm{pH}$ of horizons have received most research attention (Table 4 ). 
Table 3 Summary of soil horizon variation studies by soil order.

Horizons Alfisol Andisol Aridisol Entisol Gelisol Histosol Inceptisol Mollisol Oxisol Spodosol Ultisol Vertisol

\begin{tabular}{lllllllll}
\hline $\mathrm{O}$ & & & $\times$ & $\times$ & & & & \\
\hline $\mathrm{A}$ & $\times$ & $\times$ & & & $\times$ & $\times$ & $\times$ & $\times$ \\
\hline $\mathrm{E}$ & $\times$ & & & & $\times$ & $\times$ \\
\hline $\mathrm{B}$ & $\times$ & $\times$ & $\times$ & $\times$ & $\times$ & $\times$ & $\times$ & $\times$ \\
\hline $\mathrm{C}$ & $\times$ & & $\times$ & $\times$ & $\times$ & $\times$ \\
\hline
\end{tabular}

Vazhenin et al. (1969); Drees and Wilding (1973); Sanborn and Pawluk (1989); Stolt et al. (1993); Göttlein and Stanjek (1996); Bockheim and Tarnocai (1998); Gough et al. (2000); Deurer et al. (2000, 2003); Samouelian et al. (2011); Khitrov (2016); Grauer-Gray and Hartemink (2018); Silva et al. (2018a); Zhang et al. (2019). 
Table 4 Number of soil horizons in which selected soil properties were studied by master horizons used for Figs. 14 and 15.

Physical properties

Elements

\begin{tabular}{llllllllllllllll} 
Horizon & Horizon thickness & $\mathbf{S O C}$ & $\mathbf{p H}$ & Texture & Bulk density & $\mathbf{P}$ & $\mathbf{K}$ & $\mathbf{A l}$ & $\mathbf{F e}$ & $\mathbf{C a}$ & $\mathbf{M g}$ & $\mathbf{M n}$ & $\mathbf{S i}$ & $\mathbf{T i}$ & $\mathbf{Z r}$ \\
\hline $\mathrm{O}$ & 7 & 0 & 1 & 0 & 0 & 0 & 0 & 0 & 0 & 0 & 0 & 0 & 0 & 0 & 0 \\
\hline $\mathrm{A}$ & 3 & 56 & 16 & 53 & 4 & 6 & 11 & 11 & 14 & 8 & 2 & 6 & 9 & 8 & 8 \\
\hline $\mathrm{E}$ & 2 & 4 & 2 & 7 & 5 & 4 & 5 & 1 & 1 & 1 & 1 & 1 & 0 & 0 & 0 \\
\hline $\mathrm{B}$ & 3 & 9 & 9 & 53 & 5 & 7 & 11 & 7 & 10 & 8 & 2 & 6 & 5 & 8 & 8 \\
\hline $\mathrm{C}$ & 1 & 4 & 2 & 49 & 3 & 1 & 4 & 2 & 5 & 3 & 1 & 2 & 2 & 5 & 5 \\
\hline
\end{tabular}

Based on 13 studies. Vazhenin et al. (1969); Drees and Wilding (1973); Sanborn and Pawluk (1989); Stolt et al. (1993); Göttlein and Stanjek (1996); Bockheim and Tarnocai (1998); Gough et al. (2000); Deurer et al. (2000, 2003); Samouelian et al. (2011); Grauer-Gray and Hartemink (2018); Silva et al. (2018a); Zhang et al. (2019). 


\subsection{O horizon}

The $\mathrm{O}$ horizon is defined as a horizon or layer dominated by organic soil materials consisting of undecomposed, partially, or highly decomposed litter composed of leaves, needles, twigs, moss, or lichens (IUSS Working Group WRB, 2015). The mineral fraction constitutes only a small percentage of the volume of the material and is generally much less than half of the weight. Soil Taxonomy includes organic materials that are saturated with water for long periods (such as peat) or seldom saturated as in soils with a folistic horizon (Soil Survey Staff, 2014). An O horizon may be at the surface of the mineral soil, or at any depth below the surface if it is buried.

An $\mathrm{O}$ horizon has high soil organic matter content and dark color and is often used with the suffixes a, e, and i to indicate different degrees of organic matter decomposition. An $\mathrm{Oa}$ horizon consists of highly decomposed organic material where rubbed fiber content averages $<1 / 6$ of the volume; an Oe contains organic material of intermediate decomposition degree in which rubbed fiber content is $1 / 6$ to $2 / 5$ of the volume; and an Oi has slightly decomposed organic material in which rubbed fiber content is more than about $2 / 5$ of the volume.

In Soil Taxonomy, an $\mathrm{O}$ horizon is diagnosed with organic soil materials (fibers, fibric, hemic, sapric, humilluvic, and limnic materials) and is used to assess folistic, histic, and ochric epipedons, aquic soil moisture regime, as well as cryic soil temperature regime (Soil Survey Staff, 2014). Histic epipedons and organic soil materials are used as diagnostic criteria at all levels in Soil Taxonomy (Soil Survey Staff, 2014). An O horizon is common in Histosols but may also be found in Spodosols, Gelisols, Andisols, Alfisols, Ultisols, Inceptisols, Entisols, Vertisols, and Oxisols. Histic and folic horizons are used in diagnosing Histosols in WRB (IUSS Working Group WRB, 2015).

The few studies investigating $\mathrm{O}$ horizon variation mainly examined the horizon thickness of Gelisols and Spodosols. Gelisols often have convoluted, distorted, and discontinuous horizons as a result of cryoturbation and the formation of microtopography (Ping et al., 2013) (Fig. 11). Gough et al. (2000) studied the variation of O horizon thickness of 6-m-long transects under different vegetation in the Alaskan arctic tundra and found that the $\mathrm{CV}$ s of $\mathrm{O}$ horizon thickness at different transects ranged from $35 \%$ to $72 \%$. The large variation in horizon thickness reflected cryoturbation, but they found that average $\mathrm{O}$ horizon thickness was also related to the plant community, but could not explain the different magnitudes of variation. Bockheim and Tarnocai (1998) studied a Typic Haploturbels and showed 

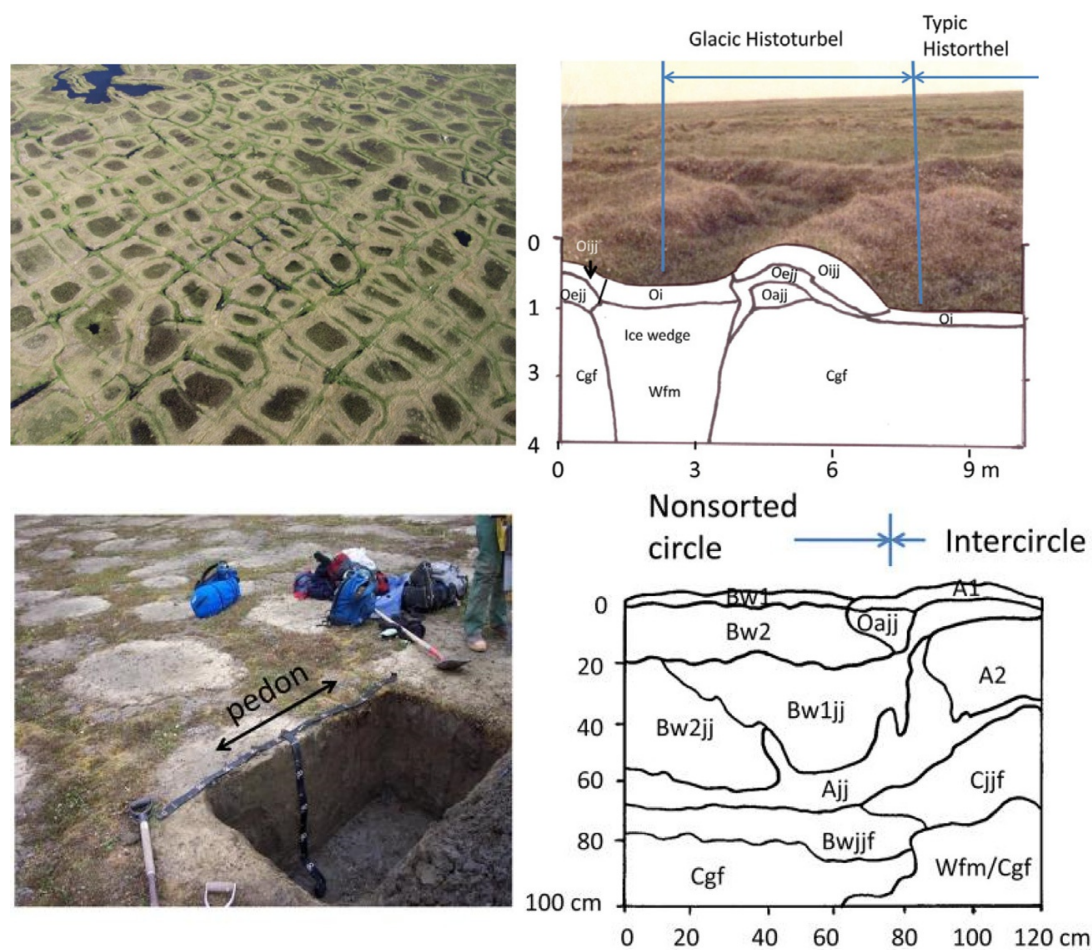

Fig. 11 Patterned ground and soil horizon variation in Gelisols of Alaska, USA. Variation in microtopography from freezing and thawing (Ping et al., 2013).

that the $\mathrm{O}$ horizon had a considerably higher variation in $\mathrm{pH}(3.10-4.24)$ than the underlying B (3.91-4.09) or C horizons (4.01-4.28).

Several early studies investigated $\mathrm{O}$ horizon variation in Spodosols. Profile drawings of three Spodosols by Lyford (1939) showed O horizons relatively parallel to the ground with slight waviness and less irregular than underlying B horizons (Fig. 10A). Vazhenin et al. (1969) studied the variation of $\mathrm{O}$ horizon thickness of a Spodosol and measured an average thickness of $6 \mathrm{~cm}$ and a CV of 35\% (Fig. 12). Solomatova and Sidorova (2008) showed that in the young spruce forest the variability of O horizon thickness increased with the age of the stand, and showed a distinct periodicity in its spatial distribution, following the patchy structure of the forest ecosystem. In the old-growth spruce forest, $\mathrm{O}$ horizons were thicker, but the regular structure in their distribution was almost absent because of overlapping cycles of the forest development and random processes such as treefalls. 


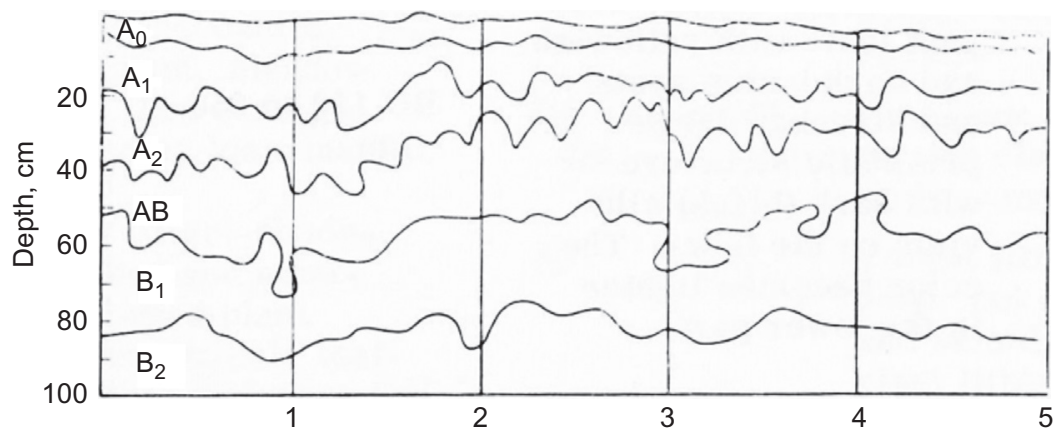

Fig. 12 Variation of horizon boundaries of a Spodosol (Sod strongly-Podzolic) from Vazhenin et al. (1969). The A0 horizon is an O horizon, and the A2 horizon is an E horizon.

\subsection{A horizon}

The A horizon is defined as a mineral horizon formed at the soil surface, or below an $\mathrm{O}$ horizon, in which all or much of the original structure of the underlying rocks or geological deposits have been obliterated. It shows one or more of the following features: an accumulation of humified organic matter mixed with the mineral fraction; properties resulting from cultivation, pasturing, or similar disturbance; or a morphology different from that of the underlying $\mathrm{E}, \mathrm{B}$, or $\mathrm{C}$ horizons, resulting from the processes related to the soil surface (IUSS Working Group WRB, 2015; Soil Survey Staff, 2014). An A horizon is not the same as an epipedon, but generally occupies a large portion of it, and A horizons are used in the diagnosis of all eight epipedons in Soil Taxonomy (Soil Survey Staff, 2014). For example, mollic epipedons are used for classifying Mollisols in Soil Taxonomy (Soil Survey Staff, 2014) and Kastanozems and Phaeozems in WRB (IUSS Working Group WRB, 2015).

Most soils contain an A horizon, but some soils have an E or B horizon directly below an $\mathrm{O}$ horizon, i.e., some Spodosols. In soils under forest, it is often difficult to distinguish the A horizon from the $\mathrm{O}$ horizon. An A horizon is often used with a $\mathrm{p}$ suffix indicating that is has been cultivated ( $\mathrm{p}$ for plowed). When an A horizon is buried under deposits such as sediments or tephra, it receives a "b" suffix (Fig. 13), and the horizon may be confused with an illuvial horizon and vice versa.

Variation in A horizons have been fairly well studied in Alfisols, Entisols, Inceptisols, Mollisols, Oxisols, and Spodosols (Table 3). The clay content 


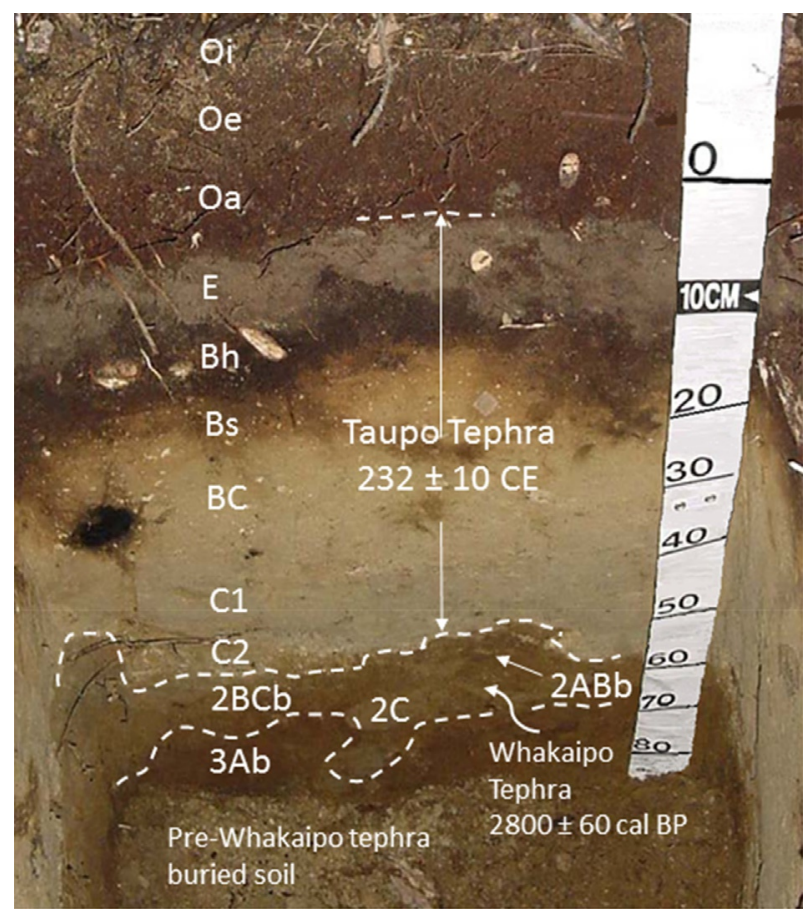

Fig. 13 Andic Haplohumods on pumiceous tephra under native forest in central North Island, New Zealand. The organic horizons would be designated (from top) L, F, and $\mathrm{H}$ in New Zealand's horizonation system, the $O$ horizon being restricted to wet organic soils on peat (Clayden and Hewitt 1989). Note wavy to irregular boundaries of lowermost buried horizons. Photo: D.J. Palmer.

(mean $\mathrm{CV}$ of $8 \%$ ) varied more than sand (mean CV of $6 \%$ ) and silt contents (mean CV of 4\%). In the A horizon, the mean CVs were $40 \%$ for soil organic carbon (SOC) but only 7\% for bulk density. The variation of most soil properties within the A horizon was lower than that in the $\mathrm{B}$ and $\mathrm{C}$ horizons (Fig. 14). The elements showed minimal variation in the A horizon of the seven soil orders; variation was greatest in the B horizon; and variation was least within the C horizon (Fig. 15).

\subsection{E horizon}

The E horizon is a mineral horizon with the main feature of eluvial loss of silicate clay, iron, aluminum, silicon, or some combination of these, leaving a residual concentration of sand and silt particles, and in which all or much of the original structure of rock or unconsolidated geological 


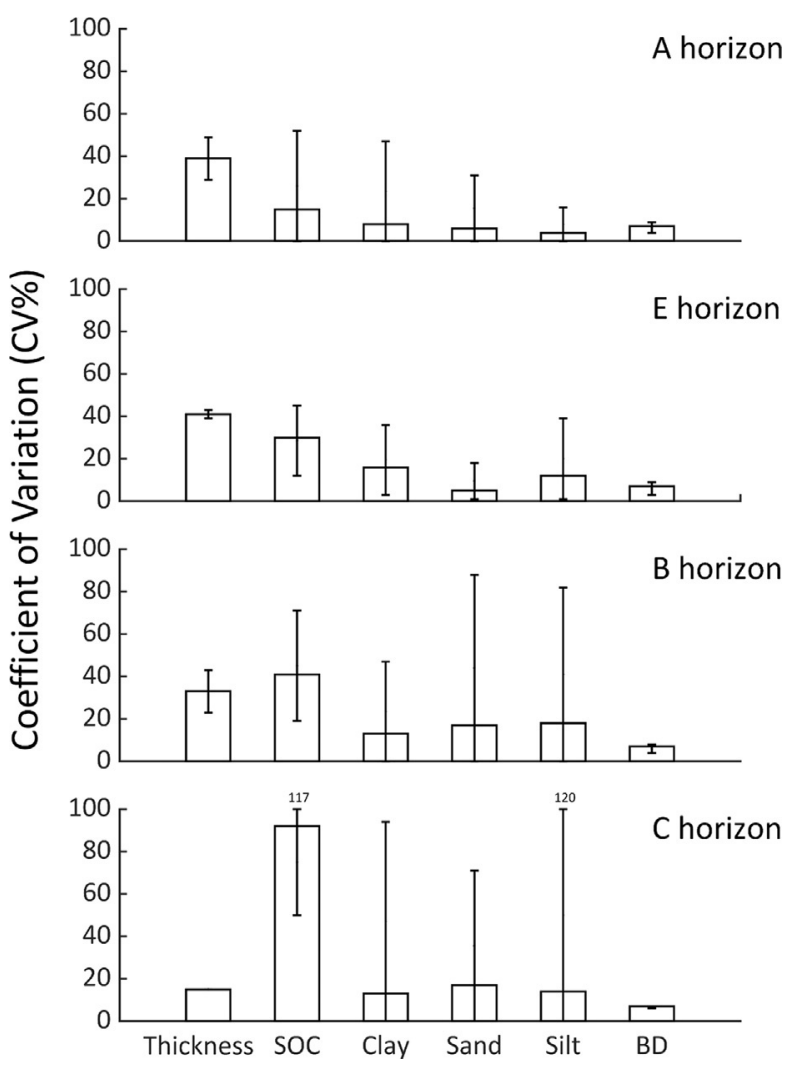

Fig. 14 Combined within-horizon variation expressed by coefficient of variation (CV\%) of selected properties of seven soil orders (Alfisols, Entisols, Gelisols, Inceptisols, Mollisols, Spodosols, and Ultisols). The bar plot shows the mean, minimum, maximum, and range of CVs (\%) for horizon thickness, soil organic carbon (SOC), clay, sand, silt, and bulk density (BD) for every master soil horizon. Graph based on 13 studies (Table 4).

material has been obliterated (IUSS Working Group WRB, 2015; Soil Survey Staff, 2014). An E horizon is often light-colored and is underlain by an illuvial horizon. The E horizon may be part of an ochric epipedon and/or albic subsurface horizon and, together with illuvial horizons, it comprises a glossic subsurface horizon (Soil Survey Staff, 2014). In an examination of 3000 official soil descriptions, Bockheim (2016) found that an albic horizon was present in seven orders and could be ranked on an area basis: Alfisols $>$ Spodosols $>$ Ultisols $>$ Mollisols $>$ Inceptisols, Entisols $>$ Aridisols. The mean thickness of the albic horizon was $19 \mathrm{~cm}$ but ranged from $90 \mathrm{~cm}$ in Alorthods to $3 \mathrm{~cm}$ in Xerolls. 

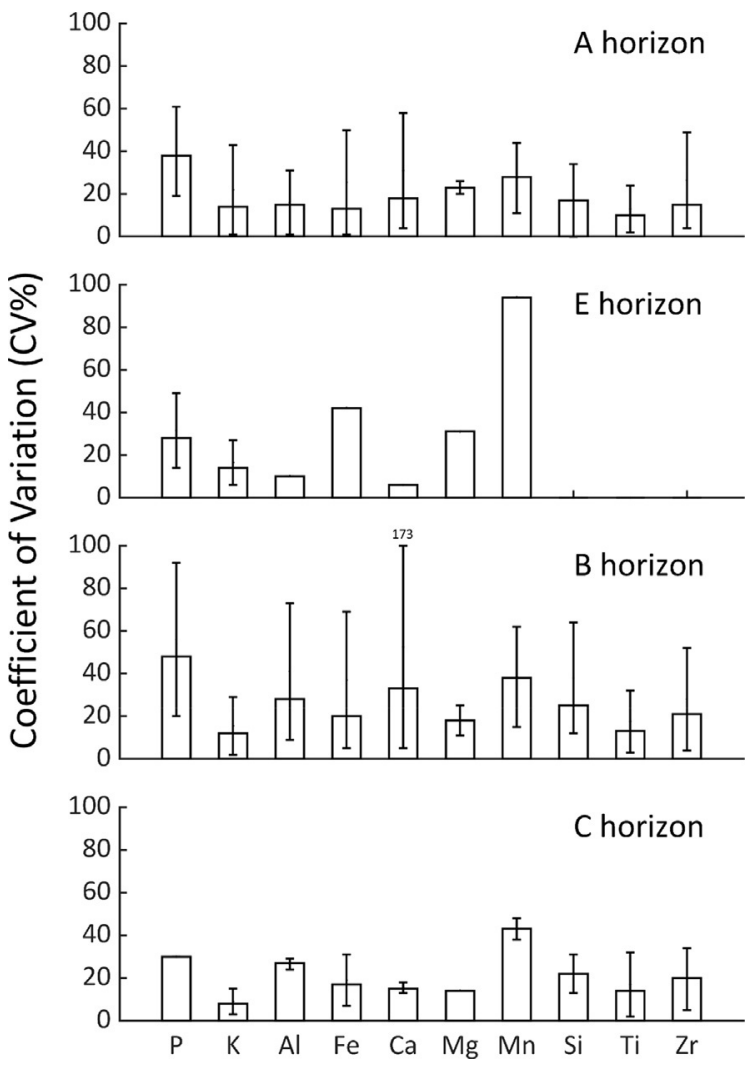

Fig. 15 Combined within-horizon variation expressed by coefficient of variation (CV\%) of content of selected elements of seven soil orders (Alfisols, Entisols, Gelisols, Inceptisols, Mollisols, Spodosols, and Ultisols). The bar plot shows the mean, minimum, maximum, and range of CVs (\%) for content of selected elements for every master soil horizon. Graph based on 13 studies (Table 4).

Soil property variation in E horizons has been measured in Spodosols (Deurer et al., 2000; Vazhenin et al., 1969), in an Alfisol (Samouelian et al., 2011), and in an Ultisol (Stolt et al., 1993). The Spodosols showed large variation in $\mathrm{E}$ horizon thickness (labeled A2 in Fig. 12) (Deurer et al., 2003; Vazhenin et al., 1969). Vazhenin et al. (1969) observed a mean E horizon thickness of $13 \mathrm{~cm}$ (CV of $39 \%$ ) similar to that found by Sidorova and Krasilnikov (2008). Deurer et al. (2003) observed a mean E horizon thickness of only $5 \mathrm{~cm}$ (CV of $43 \%)$. Sand content in E horizons showed lower variation than clay and silt contents with mean 
CVs of $5 \%$ for sand, $16 \%$ for clay, and 12\% for silt (Deurer et al., 2000; Samouelian et al., 2011; Stolt et al., 1993). In four Spodosols, the mean CVs were $30 \%$ (range of $12-45 \%$ ) for SOC and 7\% (range of 3-9\%) for bulk density (Deurer et al., 2000; Vazhenin et al., 1969). Vazhenin et al. (1969) measured the variation of elements in $\mathrm{E}$ horizons of Spodosols. The Mn content showed the highest variation, and also $\mathrm{Fe}$, $\mathrm{Mg}$, and $\mathrm{P}$ contents had considerable variation. The lowest variation was found for K, Al, and Ca contents (Fig. 12).

\subsection{B horizon}

The $\mathrm{B}$ horizon is a mineral horizon below an $\mathrm{A}, \mathrm{E}$, or $\mathrm{O}$ horizon in which all or much of the original parent material structures or bedding features have been obliterated. The $\mathrm{B}$ horizon can have a range of pedogenic features resulting from translocation of soil materials, in situ processes, or both. The B horizon may differ from the original parent material with respect to color, structure, and composition. Processes that form B horizons include illuvial concentration, alone or in combination, of (alumino)silicate clay, iron, aluminum, humus, carbonates, gypsum, or silica; removal of carbonates; residual concentration of sesquioxides; coatings of sesquioxides not coupled with illuviation of iron; alteration in situ (via weathering and synthesis/argillization) that forms crystalline aluminosilicate clays, nanocrystalline clays, or oxides or hydroxides (e.g., Churchman and Lowe, 2012) and which forms a granular, blocky, or prismatic structure if volume changes accompany changes in moisture content; and brittleness (IUSS Working Group WRB, 2015). Soil Taxonomy also includes the feature of strong gleying when accompanied by other evidence of pedogenic change (Soil Survey Staff, 2014).

The B horizon may be observed in the lower part of ochric epipedons, and it is essential in the diagnosis of subsurface illuvial horizons (agric, argillic, calcic, kandic, natric, sombric, and spodic), cemented horizons (duripan, ortstein, petrocalcic, petrogypsic, and placic), as well as other horizons (cambic, fragipan, gypsic, oxic, and salic). Subsurface horizons are used in Soil Taxonomy at all levels from soil orders to the subgroups (Soil Survey Staff, 2014). Most soils contain a B horizon except young soils or soils highly resistant to weathering (e.g., Entisols) in which an A horizon is directly underlain by a C horizon, an AC horizon or bedrock. Andisols, Gelisols, Histosols, Mollisols, and Vertisols may also lack a B horizon. 
Based on data from 14 studies, the B horizon showed greater variation than the A horizon, although the variation differed considerably between soil profiles (Figs. 14 and 15). Variation within B horizons has been studied in Alfisols, Entisols, Gelisols, Inceptisols, Mollisols, Oxisols, Spodosols, and Ultisols. The types of B horizons had various features, including accumulation of organic matter, iron, and aluminum (Bhs), iron and aluminum oxides (Bo), clay (Bt), gypsum (By), gleying (Bg), as well as weakly developed B horizons (Bw). The mean CVs were $41 \%$ for SOC and $7 \%$ for bulk density. Sand and silt content showed higher variation than clay content. The $\mathrm{B}$ horizon showed higher variation than the A horizon for most properties; however, horizon thickness was slightly more variable in A horizons than in $\mathrm{B}$ horizons. The content of elements showed high variation within the B horizon (Fig. 15). The K, Mg, and Ti contents showed relatively smaller variations but the mean $\mathrm{CVs}$ of $\mathrm{Al}, \mathrm{Fe}, \mathrm{Mn}, \mathrm{Si}$, and $\mathrm{Zr}$ contents ranged from $20 \%$ to $38 \%$. The $\mathrm{P}$ and $\mathrm{Ca}$ contents showed considerably high variations in the $\mathrm{B}$ horizon.

\subsection{C horizon}

The $\mathrm{C}$ horizon is a mineral horizon, excluding strongly cemented and hard bedrock, and the horizon is little affected by pedogenic processes and, by definition, lacks the properties of O, A, E, or B horizons (Soil Survey Staff, 2014). In WRB, the $C$ horizon also includes siliceous and calcareous layers, such as shells, coral, and diatomaceous earth (IUSS Working Group WRB, 2015). Numerous soils contain a C horizon overlying bedrock which is designated an $\mathrm{R}$ layer in Soil Taxonomy except for some highly weathered soils (e.g., Ultisols, Oxisols). In many soils, the bedrock is found below $200 \mathrm{~cm}$ depth. Soils formed in unconsolidated geological deposits, however, such as alluvium, colluvium, loess, or volcanic deposits may have bedrock at great depths. Moreover, soils formed on loess and incrementallyaccumulated thin tephra deposits commonly have no $\mathrm{C}$ horizon because all parts of such soils will show evidence of pedogenic alteration (e.g., Fig. 5; Lowe, 2019; Lowe and Tonkin, 2010).

Some studies have investigated the $\mathrm{C}$ horizon variation of Alfisols, Gelisols, Inceptisols, Spodosols, and Ultisols (Table 3). The SOC showed considerably high variation with a mean $\mathrm{CV}$ of $92 \%$ and a range of 50-117\%. The bulk density showed small and similar variations (mean $\mathrm{CV}$ of $7 \%$ ) compared with those of A and B horizons. The texture (sand, 
silt, and clay) showed high variations in the C horizon compared with the variations of the above horizons (Fig. 14). There were fewer studies on elemental content variation in $\mathrm{C}$ horizon and the variation was lower than in the $\mathrm{A}$ and $\mathrm{B}$ horizons (Fig. 15).

\section{Case studies}

\subsection{Spodosols and Histosols-Russia}

Soil horizon variation in a landscape scale was studied in southern Karelia, in northern European Russia (WGS84 $61.90^{\circ} \mathrm{N}, 32.82^{\circ} \mathrm{E}$ ). The study was conducted on a $1-\mathrm{km}^{2}$ forested plot and auger observations were made at a $100 \times 100$ grid. In total, 100 soil profiles to a depth of $50-70 \mathrm{~cm}$ were described morphologically and sampled for the analysis of bulk density, SOC, $\mathrm{pH}$, and texture. The dominant soils were Spodosols (sandy loamy, mixed, superactive, frigid Typic Haplorthods and Typic Endoaquods) and Histosols (dysic, frigid, Hemic Haplofibrists). In total, 66 soils were Haplorthods and Endoaquods, 33 soils were Histosols, and one soil was a Halaquepts.

The 67 mineral soils had a forest litter O horizon, and 66 of them had a spodic horizon (Bs). Most mineral soils had A horizons, and less than a half of the soils had an E horizon: in most soils the E horizon was discontinuous, and it was only sampled $(n=28)$ if its depth exceeded $5 \mathrm{~cm}$ and was not sporadic. Thin $\mathrm{E}$ horizons were recorded in the morphological description. The results of the measurements are presented in Table 5. Clay content was not measured in organic horizons, and the depth of Oi horizon was not recorded in Histosols, because in most places the depth of the organic layer was deeper than the profiles studied and deeper than the soil auger $(1.5 \mathrm{~m})$ could reach.

We classified the continuity of the horizons according to the method developed by Dmitriev (1983), who evaluated the continuity of soil horizons using formal criteria. He used the following measures (in $\mathrm{cm}$ ): $\mathrm{X}$ the horizontal size of a separate fragment (spot) of a horizon; Y-horizontal distances between points; 1(critical) — a square root of the depth range of the horizon (e.g., 1 for the depth less than $2 \mathrm{~cm}, 2$ for the depth range $2-5 \mathrm{~cm}, 3$ for the range $6-10 \mathrm{~cm}$, etc.); and $\mathrm{L}$ (critical) — a square root from the depth of soil profile ( $\mathrm{A}+\mathrm{B}$ horizons). A soil horizon is:

- continuous if $\mathrm{Y}<1$ (critical)

- discontinuous if $\mathrm{X}>\mathrm{L}$ (critical) and 1 (critical) $<\mathrm{Y}<\mathrm{L}$ (critical)

- fragmented if 1 (critical) $<\mathrm{X}<\mathrm{L}$ (critical) and 1 (critical) $<\mathrm{Y}<\mathrm{L}$ (critical) 
Table 5 Horizon thickness and soil properties variation (mean + CV\%) in Spodosols $(n=66)$, Inceptisol $(n=1)$, and Histosols $(n=33)$ on a $1 \mathrm{~km}^{2}$ plot, southern Karelia, Russia.

\begin{tabular}{|c|c|c|c|c|c|c|c|}
\hline & Horizon & $\begin{array}{l}\text { \# of } \\
\text { samples }\end{array}$ & $\begin{array}{l}\text { Horizon } \\
\text { thickness } \\
(\mathrm{cm})\end{array}$ & $\begin{array}{l}\text { SOC } \\
(\%)\end{array}$ & $\begin{array}{l}\mathrm{pH} \\
(\mathrm{KCl})\end{array}$ & $\begin{array}{l}\text { Clay } \\
\text { content } \\
(\%)\end{array}$ & $\begin{array}{l}\text { Bulk } \\
\text { density } \\
\left(\mathrm{Mg} \mathrm{m}^{-3}\right)\end{array}$ \\
\hline \multirow[t]{4}{*}{$\begin{array}{l}\text { Spodosols, } \\
\text { Inceptisol }\end{array}$} & $\mathrm{O}$ & 67 & $5.8(42 \%)$ & $\begin{array}{l}30.6 \\
(34 \%)\end{array}$ & $\begin{array}{l}4.1 \\
(10 \%)\end{array}$ & na & $0.24(69 \%)$ \\
\hline & A & 60 & $13.4(34 \%)$ & $\begin{array}{l}3.3 \\
(34 \%)\end{array}$ & $\begin{array}{l}3.7 \\
(7 \%)\end{array}$ & $\begin{array}{l}5.5 \\
(47 \%)\end{array}$ & $0.96(15 \%)$ \\
\hline & $\mathrm{E}$ & 28 & $12.1(36 \%)$ & $\begin{array}{l}0.4 \\
(44 \%)\end{array}$ & $\begin{array}{l}4.0 \\
(5 \%)\end{array}$ & $\begin{array}{l}2.9 \\
(30 \%)\end{array}$ & $1.33(8 \%)$ \\
\hline & Bs & 66 & $24.6(35 \%)$ & $\begin{array}{l}1.5 \\
(56 \%)\end{array}$ & $\begin{array}{l}4.5 \\
(5 \%)\end{array}$ & $\begin{array}{l}5.7 \\
(41 \%)\end{array}$ & $1.13(16 \%)$ \\
\hline Histosols & Oi & 33 & na & $\begin{array}{l}47.7 \\
(4 \%)\end{array}$ & $\begin{array}{l}3.5 \\
(12 \%)\end{array}$ & na & $0.11(66 \%)$ \\
\hline
\end{tabular}

na indicates not available.

- $\quad$ sporadic if 1 (critical) $<\mathrm{X}<\mathrm{L}$ (critical) and $\mathrm{Y}>\mathrm{L}$ (critical), and

- absent if $\mathrm{X}<1$ (critical) and $\mathrm{Y}>\mathrm{L}$ (critical).

If both $\mathrm{X}$ and $\mathrm{Y}$ exceed $\mathrm{L}$ (critical) there are probably two soil taxonomic units. Using the terminology proposed by Dmitriev (1983), the E horizon was continuous in nine Spodosol profiles, discontinuous in 16, fragmented in 21, sporadic in 12, and absent in eight Spodosols.

The thickness of the $\mathrm{O}$ horizons of the Spodosols and Inceptisol varied, and it had the highest CV for horizon thickness (42\%). The thickness of the mineral horizons (A, E, B) had CVs between 34\% and 36\%. The highest CV for SOC concentration was found in the Bs horizons (56\%) followed by the E horizons (44\%). For the $\mathrm{O}$ and $\mathrm{A}$ horizons (Spodosols and Inceptisol), the variation of SOC was lower (CVs of 34\%). High variation of SOC in the spodic horizon was the result of the illuviation of organic substance that depended on the topographical position of the soils. The lowest variation of SOC was found in the Oi horizons of Haplofibrists (CV of 4\%): these horizons contained poorly decomposed mosses with little variation in chemical composition. The $\mathrm{pH}$ variation was low in all the horizons, and the lowest variation was found in the $\mathrm{E}$ and Bs horizons (CVs of $5 \%$ ). In the A horizon, the variation was slightly higher (CV of $7 \%$ ), and the highest variation occurred in forest litter (CV of 10\%) and peat (CV of $12 \%)$. The clay content varied considerably in the A (CV of 47\%) and Bs (CV of 41\%) horizons, and its variation was lower in the E horizon (30\%). Bulk density varied 
in the organic horizons (CVs of 66-69\%), and the high variation measured may have been resulted from the difficulty in sampling fibrous organic materials. For the mineral horizons, the variation of $\mathrm{BD}$ was relatively low, with CVs of $15 \%$ and $16 \%$ for the A and Bs horizons, respectively, and a CV of $8 \%$ for the E horizon.

\subsection{Alfisol and Mollisol-USA}

Soil horizon variations studies were conducted in a Mollisol and Alfisol in Wisconsin, USA. The Mollisol (fine-loamy, mixed, superactive, mesic Pachic Argiudolls; Troxel series) (Fig. 16) was studied in south central Wisconsin (WGS84 $43.07^{\circ} \mathrm{N}, 89.54^{\circ} \mathrm{W}$ ). The profile was located at the footslope position, and the soil was moderately well-drained to well-drained. The soil was formed in loess over outwash underlain by dolostone bedrock. Five horizons were identified in the field down to $1 \mathrm{~m}$ depth, and the soil contained a buried A horizon at $59 \mathrm{~cm}$ depth (Fig. 16).

The Ap1 horizon $(0-18 \mathrm{~cm})$ had granular structure and silt loam texture, with very dark brown (10YR 2/2, moist) and dark grayish brown (10YR 4/2, dry) colors. The Ap2 horizon $(18-39 \mathrm{~cm})$ had platy structure and silt loam texture, with very dark brown (10YR 2/2, moist) and dark grayish brown (10YR 4/2, dry) colors. The A2 horizon $(39-59 \mathrm{~cm})$ had subangular blocky structure and silt loam texture, with very dark brown (10YR 2/2, moist) and dark grayish brown (10YR 4/2, dry) colors. The thick A horizon (Ap1, Ap2, A2) was formed in sediments from topsoil erosion higher in the landscape. The Ab horizon (59-77 cm) had subangular blocky structure and silt loam texture, with black (10YR 2/1, moist) and dark grayish brown (10YR 4/2, dry) colors. The Bt horizon $(77-100 \mathrm{~cm})$ had angular blocky structure and silty clay loam texture, with dark yellowish brown (10YR 3/4, moist) and yellowish brown (10YR 5/4, dry) colors (Grauer-Gray and Hartemink, 2016).

The Alfisol (fine-silty over clayey, mixed, superactive, mesic Typic Hapludalfs; NewGlarus series) (Fig. 17) was studied in the Driftless Area of Wisconsin (WGS84 $43.03^{\circ} \mathrm{N}, 90.05^{\circ} \mathrm{W}$ ). The soil profile was at the shoulder position with a $6 \%$ slope. The soil was formed in loess over a mixture of sand, clay, and glauconite weathered from the underlying sandstone, dolomite, and shale bedrock. Three horizons were identified in the field down to $1 \mathrm{~m}$ depth. The Ap horizon $(0-22 \mathrm{~cm})$ had granular and subangular blocky structure and silt loam texture, with very dark grayish brown (10YR $3 / 2$, moist) and light brownish gray (10YR 6/2, dry) colors. The Bt horizon $(22-68 \mathrm{~cm})$ had subangular blocky structure and silty clay loam texture, with dark yellowish brown (10YR 4/4, moist) and light yellowish brown (10YR 6/4 dry) colors. The 2Bw horizon $(68-100 \mathrm{~cm})$ had subangular 

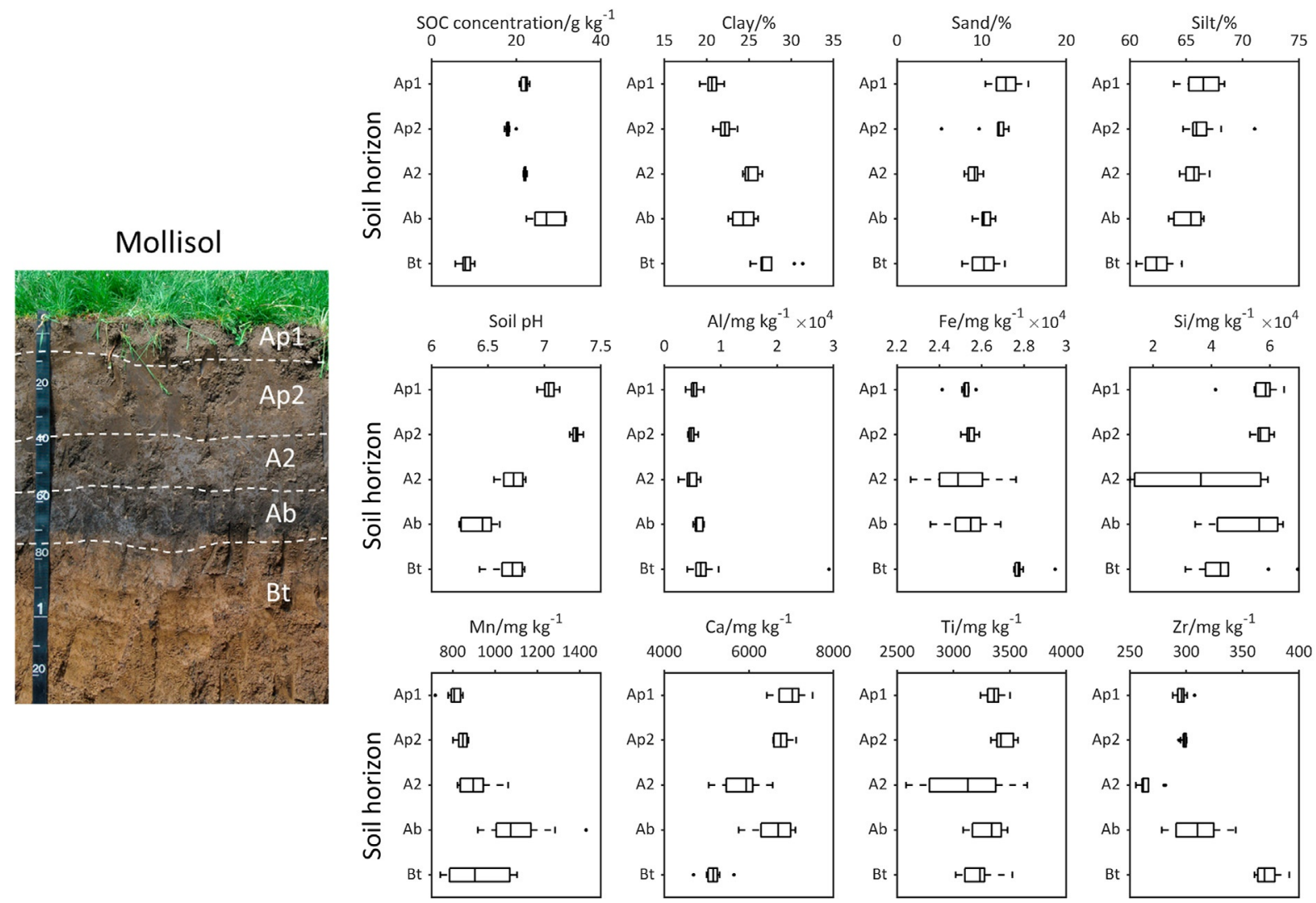

Fig. 16 Soil property variation in horizons of a Mollisol from south central Wisconsin, USA. Ten samples were taken from each soil horizon across $1 \mathrm{~m}$. 

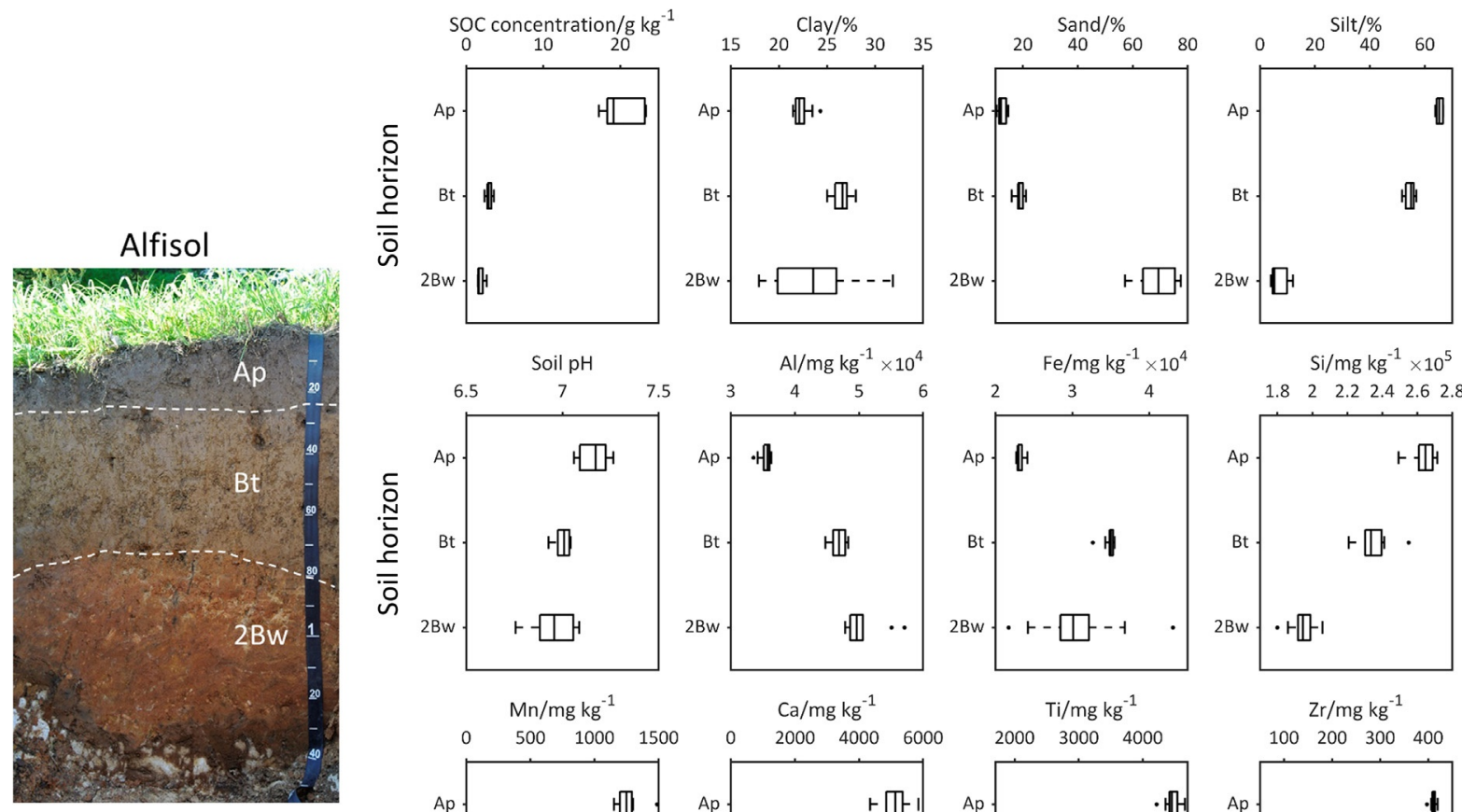

$\mathrm{Si} / \mathrm{mg} \mathrm{kg}^{-1} \times 10^{5}$
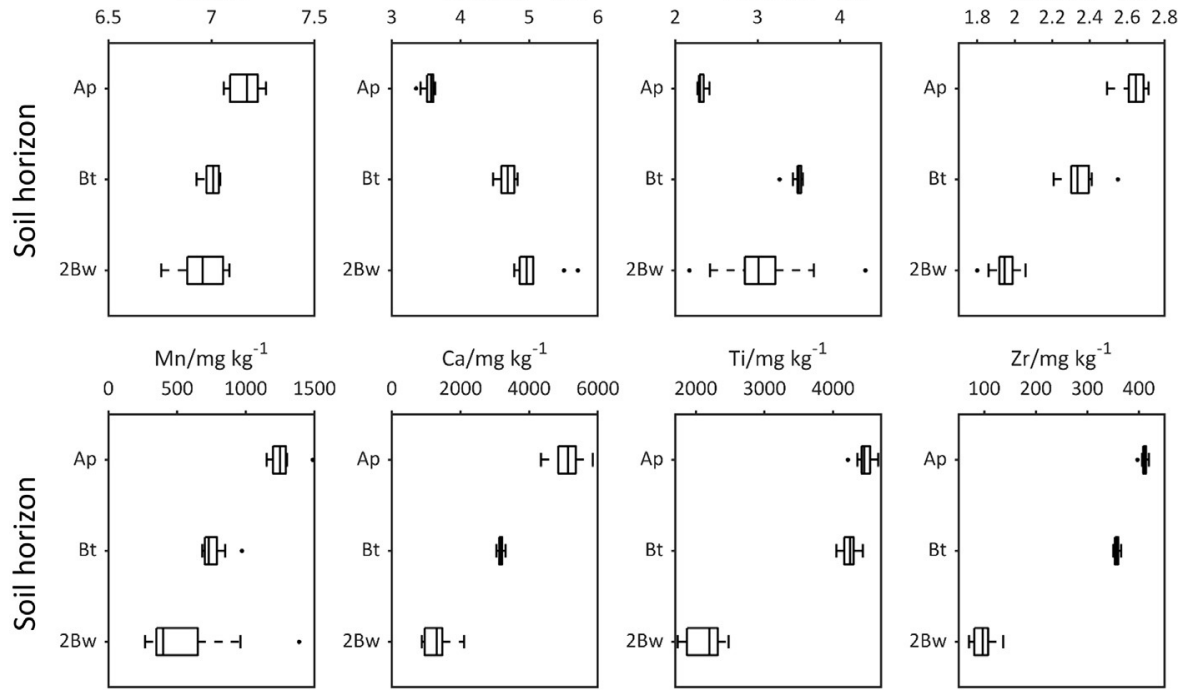

$\mathrm{Zr} / \mathrm{mg} \mathrm{kg}^{-1}$ $100200 \quad 300 \quad 400$

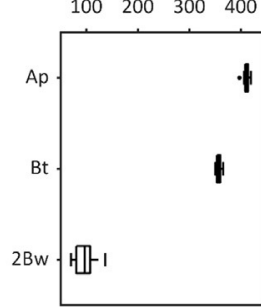

Fig. 17 Soil property variation in horizons of an Alfisol from south central Wisconsin, USA. Ten samples were taken from each soil horizon across $1 \mathrm{~m}$. 
blocky structure and sandy clay loam texture, with strong brown (7.5YR 4.5/7, moist) and strong brown (7.5YR 5/7 dry) colors.

The Alfisol and Mollisol profile walls $(1 \times 1 \mathrm{~m})$ were divided into a $10 \times 10 \mathrm{~cm}$ raster. One sample was collected at the center of each cell for a total of 100 samples. The samples were air-dried, ground, and sieved to a diameter smaller than $2 \mathrm{~mm}$. All samples were analyzed for SOC (dry combustion), soil $\mathrm{pH}$ (1:1 soil-water suspension), particle-size (hydrometer method), and elements ( $\mathrm{Al}, \mathrm{Fe}, \mathrm{Si}, \mathrm{Mn}, \mathrm{Ca}, \mathrm{Ti}$, and $\mathrm{Zr}$ ) using a portable $\mathrm{X}$-ray fluorescence ( $\mathrm{pXRF}$ ) spectrometer.

The distributions of soil properties with depth are presented in Fig. 16 for the Mollisol and in Fig. 17 for the Alfisol. In the Mollisol, both the highest concentrations and the highest variation of SOC occurred in the buried $\mathrm{A}(\mathrm{Ab})$ horizon. The $\mathrm{pH}$, clay, sand, and silt contents showed relatively uniform variation with depth. The low heterogeneity in the topsoil might be from mixing due to cultivation. Most elemental concentrations showed higher variation below $40 \mathrm{~cm}$ depth (A2, $\mathrm{Ab}$, and $\mathrm{Bt}$ horizons). In the Alfisol, the SOC content decreased exponentially with depth and had higher variation in the topsoil. Soil $\mathrm{pH}$ showed higher variation in the topsoil and the subsoil below $70 \mathrm{~cm}$ (2Bw horizon), but smaller variation in the subsoil directly below the topsoil (Bt horizon). Clay, sand, silt contents, and most elemental concentrations showed higher variation below $70 \mathrm{~cm}$ (2Bw horizon) than at $0-70 \mathrm{~cm}$ (Ap and Bt horizons).

Comparisons of horizontal and vertical CVs are displayed in Fig. 18 for the combination of A horizons (Ap1, Ap2, A2, and Ab) of the Mollisol and in Fig. 19 for the combination of $\mathrm{B}$ horizons (Bt and 2Bw) of the Alfisol. In the A horizons of the Mollisol, different soil properties showed a different magnitude of variation. The $\mathrm{Si}$ and $\mathrm{Al}$ contents showed high variation both horizontally and vertically. The sand content had a higher variation than the clay and silt contents in both directions. Most soil properties (SOC, clay, sand, $\mathrm{Mn}, \mathrm{Ca}$, and $\mathrm{Zr}$ ) showed larger vertical than horizontal variation. Several soil properties (Fe, Si, and $\mathrm{Ti}$ ) had higher CVs in the vertical direction, but a larger range of CVs in the horizontal direction. In the $\mathrm{B}$ horizons of the Alfisol, the vertical CVs were greater than the horizontal CVs for all of the soil properties, whereas for the majority of the properties (clay, silt, Al, $\mathrm{Fe}, \mathrm{Mn}, \mathrm{Ca}, \mathrm{Ti}$, and $\mathrm{Zr}$ ), a larger range of $\mathrm{CV}$ s occurred in the horizontal direction (Fig. 19). The sand and silt contents showed considerably larger vertical CVs than CVs of other properties.

The vertical variation is generally larger than the horizontal variation in soil profiles. Within soil horizons, Vazhenin et al. (1969) found that vertical 

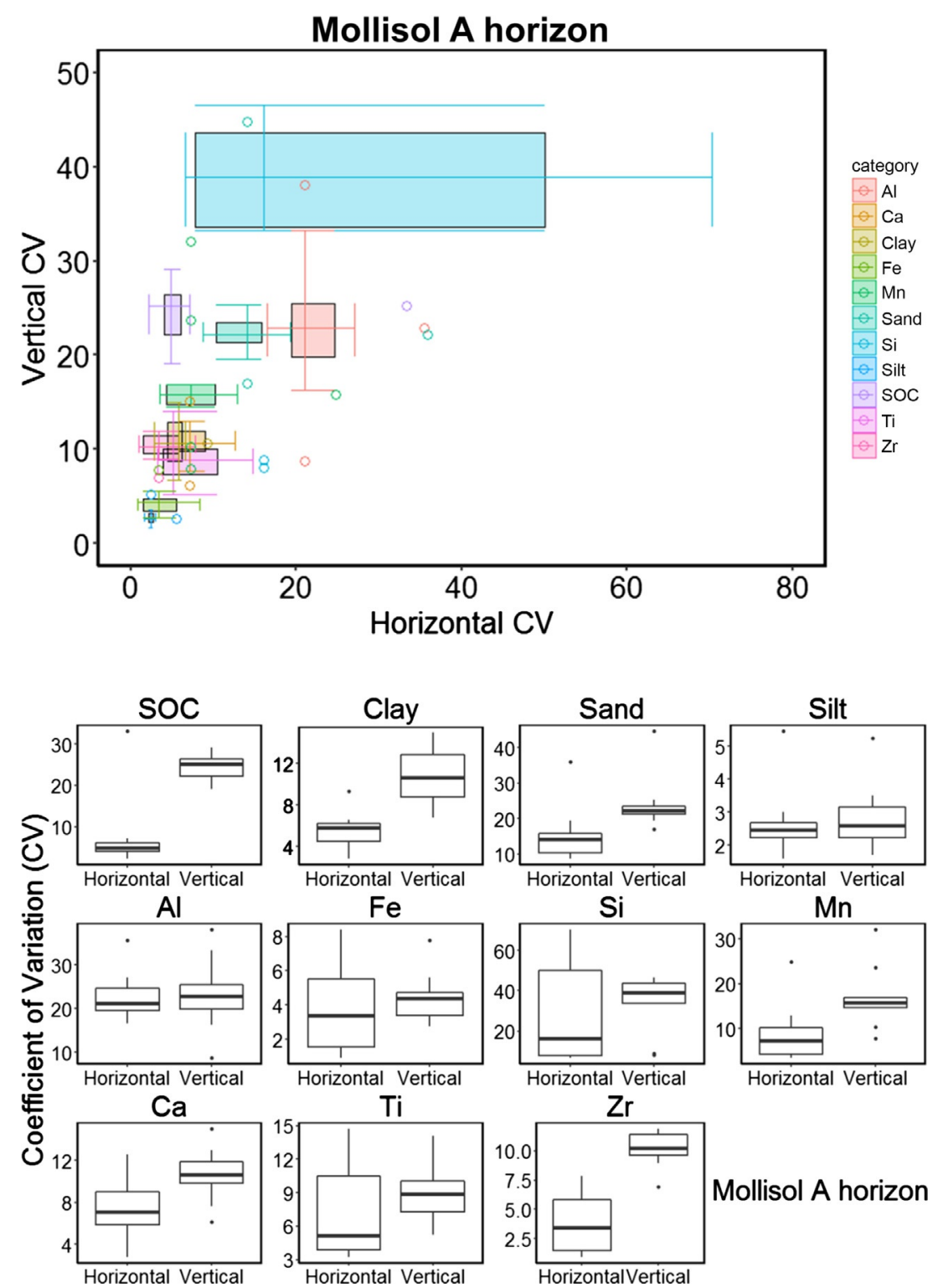

$\mathrm{Fe}$

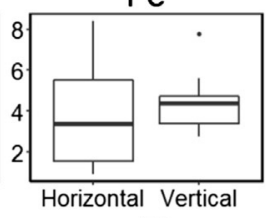

$\mathrm{Si}$

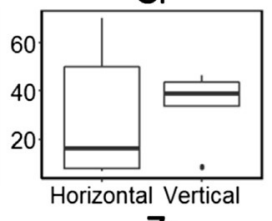

$\mathrm{Mn}$

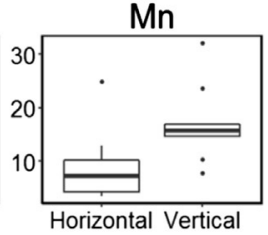

Fig. 18 Comparison of horizontal and vertical coefficients of variation (CVs\%) in A horizons (Ap1, Ap2, A2, and Ab) of a Mollisol in south central Wisconsin, USA. The boxplot shows the median, first and third quartiles, and outliers of the data. 

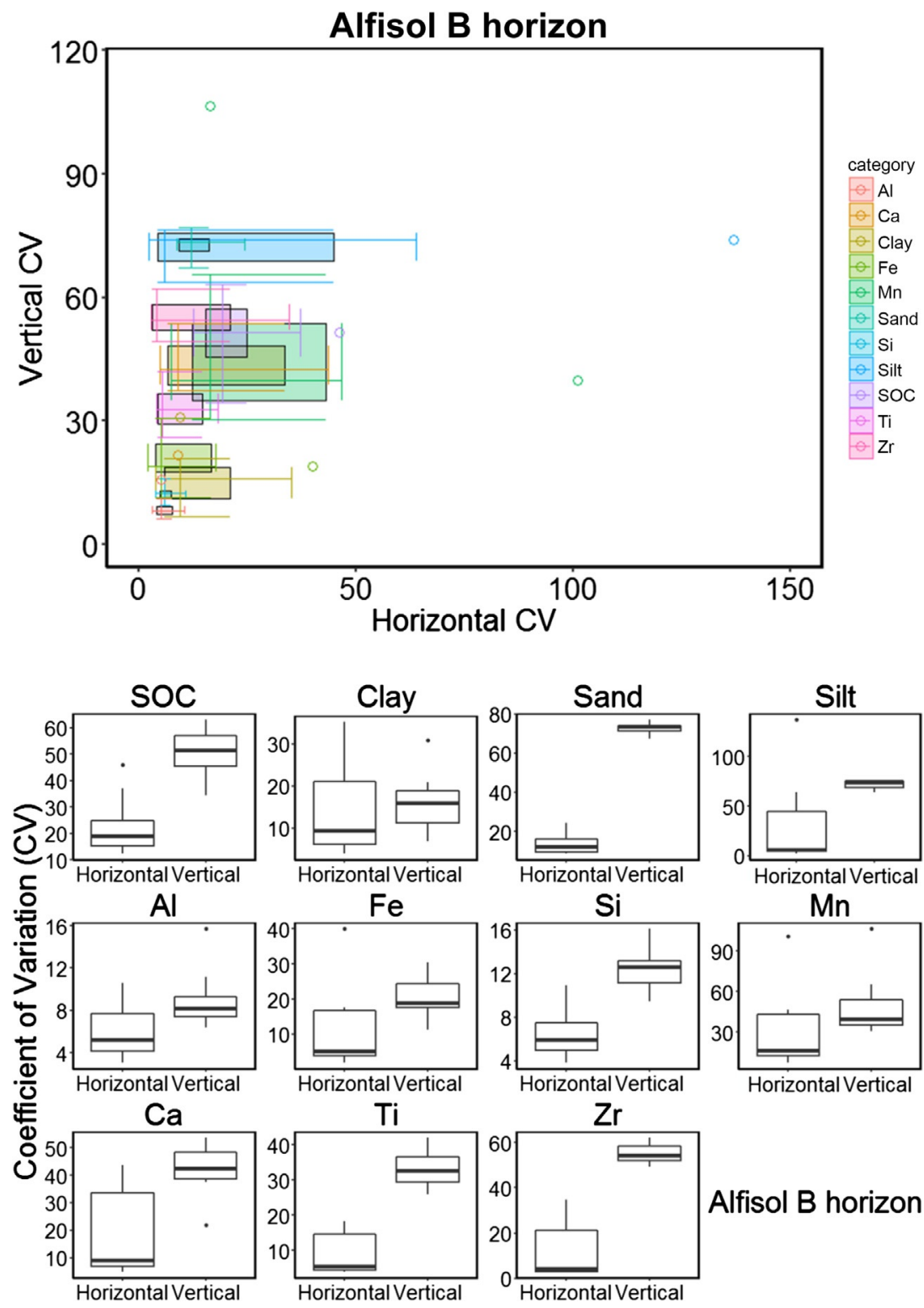

Horizontal Vertical

Fig. 19 Comparison of horizontal and vertical coefficients of variation (CVs\%) in $\mathrm{B}$ horizons ( $\mathrm{Bt}$ and $2 \mathrm{Bw}$ ) of an Alfisol in south central Wisconsin. The boxplot shows the median, first and third quartiles, and outliers of the data. 
and horizontal variation of individual soil properties were of the same order of magnitude. In the Mollisol and the Alfisol of this case study, the A and B horizons contained sub-horizons, and so larger CVs were observed vertically than horizontally. Several soil properties had larger CVs in the horizontal direction. The larger range of horizontal CVs was observed in the $\mathrm{Ab}$ horizon of the Mollisol. In the Alfisol, the larger range of horizontal CVs was observed at $70-80 \mathrm{~cm}$ which may indicate a wavy boundary between the $\mathrm{Bt}$ and $2 \mathrm{Bw}$ horizon.

\subsection{Oxisol-Brazil}

Oxisols are the dominant soil in Brazil, and most have the following properties: low activity clay composed of kaolinite and $\mathrm{Fe}$ - and $\mathrm{Al}$-oxides (e.g., hematite, goethite, and gibbsite), low $\mathrm{CEC}$, low $\mathrm{pH}$, generally low in nutrients, very deep, and no increase in clay content with depth. As soils undergo weathering over prolonged periods, most become more homogeneous (Birkeland, 1999). However, morphologically homogeneous Oxisols present some variation within and between horizons.

An Oxisol (very fine clayey, sesquic, isothermic Anionic Acrudox) under native vegetation and derived from gabbro was described in Lavras, Minas Gerais state, Brazil (WGS84 $21.23^{\circ} \mathrm{S}, 44.98^{\circ} \mathrm{W}$ ). Five horizons were identified to a depth of $1 \mathrm{~m}$. The A horizon $(0-8 \mathrm{~cm})$ had a granular structure and clayey texture (70\% clay), with dusky red (10R 3/4, moist) and weak red (10R 5/4, dry) colors. The AB horizon had a granular structure and clayey texture ( $71 \%$ clay), with weak red (10R 4/3, moist, and 10R 5/3, dry) colors. The Bo1 horizon had a granular structure, clayey texture ( $72 \%$ clay), and dark red (10R 3/6 moist) and weak red (10R 4/4, dry) colors. The Bo2 horizon had a granular structure, clayey texture ( $72 \%$ clay), and dark red (10R 3/6, moist) and red (10R 4/6, dry) colors. The Bo3 horizon had a granular structure, clayey texture (72\% clay), and dark red (10R 3/6, moist) and red (10R 4/6, dry) colors.

Three soil samples were collected from each horizon of the Oxisol and analyzed for elemental content using a pXRF spectrometer (Bruker ${ }^{\circledR}$ model $\mathrm{S} 1$ Titan LE), in triplicate, for $60 \mathrm{~s}$, in the Trace (dual soil) mode using the Geochem software. The contents of $\mathrm{SiO}_{2}, \mathrm{Fe}, \mathrm{Al}_{2} \mathrm{O}_{3}, \mathrm{~K}_{2} \mathrm{O}$, Ti, and $\mathrm{Zr}$ were obtained, and their variability within horizons was analyzed through boxplots and coefficients of variation.

The Oxisol contained considerable variation of $\mathrm{SiO}_{2}, \mathrm{Fe}, \mathrm{Al}_{2} \mathrm{O}_{3}, \mathrm{~K}_{2} \mathrm{O}$, $\mathrm{Ti}$, and $\mathrm{Zr}$ contents within and between horizons (Fig. 20). The $\mathrm{SiO}_{2}, \mathrm{Fe}$, and $\mathrm{K}_{2} \mathrm{O}$ contents differed considerably between the $\mathrm{A}$ horizon and the 

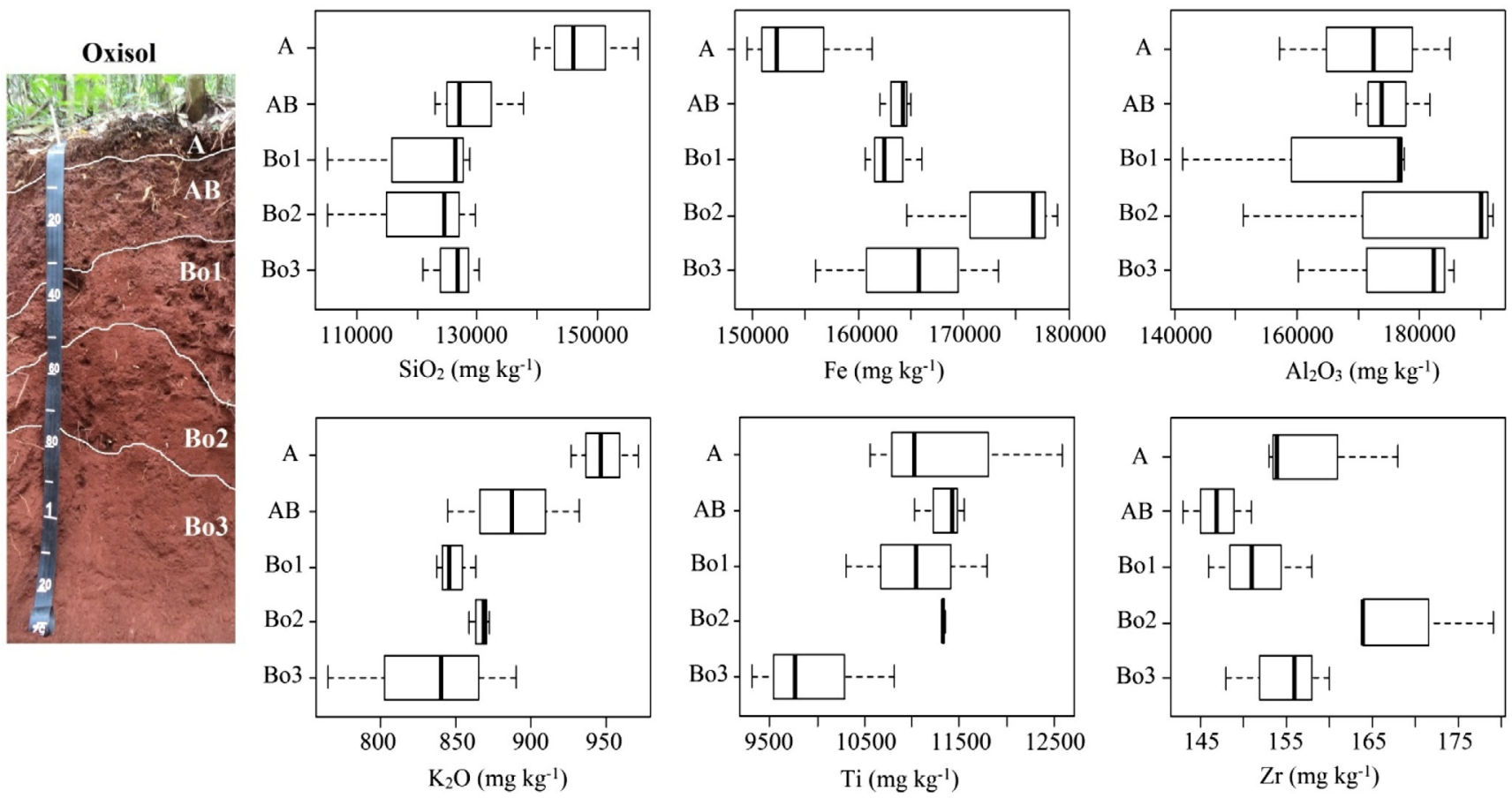

Fig. 20 Comparison of horizontal and vertical variation of elemental contents in an Oxisol profile from Brazil. The boxplot shows the median, first and third quartiles of the data. 
deeper horizons, but their variation within horizons was not very large. For $\mathrm{Fe}$ and $\mathrm{K}_{2} \mathrm{O}$, the greatest within-horizon variation occurred in the $\mathrm{Bo} 3$ horizon, whereas, for $\mathrm{SiO}_{2}$, it occurred in the $\mathrm{Bo} 2$ horizon. For $\mathrm{Al}_{2} \mathrm{O}_{3}$, the boxplots per horizon varied in the same range for all horizons, although the greatest within-horizon variation occurred in the Bo1 and Bo2 horizons. The Ti content differed considerably between the Bo3 horizon and the upper horizons, but the greatest within-horizon variation occurred within the A horizon. The $\mathrm{Zr}$ content varied considerably both between and within horizons.

Fig. 21 shows the coefficient of variation within horizons. The greatest CVs were obtained for $\mathrm{Al}_{2} \mathrm{O}_{3}$ and $\mathrm{SiO}_{2}$ in the $\mathrm{Bo} 1$ and $\mathrm{Bo} 2$ horizons. $\mathrm{SiO}_{2}$ had the greatest $\mathrm{CV}$ in the $\mathrm{AB}$ horizon and $\mathrm{Ti}$ had the greatest $\mathrm{CV}$ in the A horizon. $\mathrm{Al}_{2} \mathrm{O}_{3}$, Ti, and $\mathrm{K}_{2} \mathrm{O}$ were the most variable elements (oxides) in the $\mathrm{Bo} 3$ horizon. $\mathrm{Ti}$ and $\mathrm{Zr}$, which are commonly used elements for studying soil genesis and parent material discontinuities (Stockmann et al., 2016), also presented some variability within horizons. In A, Bo1, and $\mathrm{Bo} 2$ horizons, $\mathrm{K}_{2} \mathrm{O}$ was among the least variable elements (oxides).

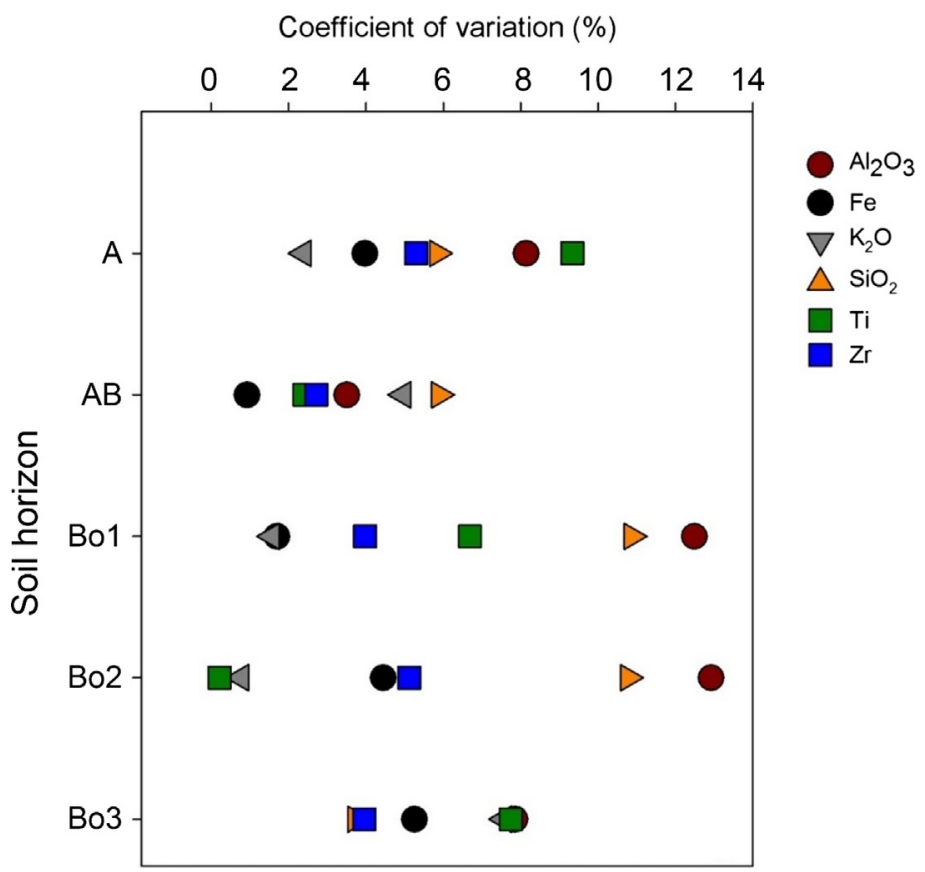

Fig. 21 Coefficient of variation (CV\%) of elements and oxides in five horizons of an Oxisol profile in Brazil. 
These results indicate that within-horizon investigations in greater detail are capable of demonstrating the variability of soil properties even in very weathered and strongly leached soils, such as Oxisols.

\section{Discussion}

\subsection{Within-horizon variation}

We reviewed lateral and vertical within-horizon variation in master horizons based on 13 studies, 76 soil profiles, and three detailed case studies. Within-horizon variation changes with depth and such variation differs for different soil properties. The variation of SOC and texture is lower in A horizons than in $\mathrm{B}$ or $\mathrm{C}$ horizons. The $\mathrm{E}$ horizon showed low variations of SOC and sand content (Fig. 14). The variation of silt content increased with depth. The variation of horizon thickness was similar for the A, E, and B horizons with CVs of approximately $40 \%$. The bulk density showed lower variation than other properties with CVs of approximately $10 \%$ in all of the master horizons. The variation of the elemental concentrations was higher in the $\mathrm{A}$ and $\mathrm{B}$ horizons than that in the $\mathrm{C}$ horizon so the variation decreased with depth.

Vazhenin et al. (1969) found that horizon variation increased from bottom to top (i.e., from $\mathrm{C}$ to the A horizons) in Spodosols and Mollisol. However, other studies showed that the CVs of subsoils were greater or equal to those of the topsoils (Beckett, 1967; Raupach, 1951b). Patterson and Wall (1982) studied the variation of A, B, and C horizons in 41 pedons and found that the subsoil horizons ( $\mathrm{B}$ and $\mathrm{C}$ horizons) have higher variation than the topsoil horizon (A horizon). In the studies summarized in Figs. 14 and 15 , we found that the $\mathrm{B}$ horizon had higher variation than that of the A horizon for most soil properties. The $\mathrm{C}$ horizon had higher variation in soil texture than that of the A horizon, but lower variation for element contents. In the Mollisol and Alfisol (Figs. 16 and 17), the subsoil showed higher variation than the topsoil. The A horizon is often older, is active in supporting plant growth, interacts with atmosphere and biosphere, and has high microbial activity. Any of these factors alone or in combination may lead to more variation and dynamic changes in the A horizon than in the underlying horizons. However, in soils under agriculture, the A horizon tended to be more uniform due to the mixing by cultivation. Tillage and liming may also result in the breakdown of an underlying E horizon (Seelig et al., 1990). 
Several natural and human induced factors (e.g., fertilization, tillage, parent material, and drainage) affect the variation within horizons. Variation can be increased by the application of fertilizers, and it is generally higher for fertilized fields than unfertilized fields (Beckett, 1967; Cline, 1944). Variation is also higher during the growing season or shortly after the growing season, but it is often lowered by tillage (Gallagher and Herlihy, 1963; Raupach, 1951b).

Parent material has a profound effect on soil horizons and their variation. According to Patterson and Wall (1982), the variation of clay and sand contents was related to the mode of deposition. Soils developed from till and shallow-water lacustrine sediments showed higher CV for clay and sand contents than for the soils developed from deep-water lacustrine sediments. Wall and Marsh (1988) found that the variation of $\mathrm{Zn}$ differed between shallow- and deep-water lacustrine sediments, with higher variation occurring in shallow-water lacustrine deposits. Drees and Wilding (1973) reported that variation from different parent materials increased from loess to till to outwash deposits. Well-drained soils showed reduced variation compared to that of imperfectly drained soils (Wall and Marsh, 1988), but Patterson and Wall (1982) did not find any effect of drainage.

The variation in soil horizons varies among soil orders although soil horizon variation has not been systematically studied in all soil orders. Vazhenin et al. (1969) found greater microvariation in the Spodosol soil profiles than in the Mollisol soil profile. Soils in dry areas have been under-researched, whereas soils with distinct features (such as Spodosols and Vertisols) have received the most research attention (Hartemink, 2015). In the soil horizon variation studies (Table 3), Spodosols received the most attention. Variations within Gelisol horizons have been studied in relation to cryoturbation features (Fig. 11). We did not find quantitative studies on horizon variation of Andisols or Aridisols. We do not have the data to systematically investigate soil horizon variation for different soil orders.

The magnitude of variation differs for soil properties. Moisture content showed a larger variation than bulk density (Vazhenin et al., 1969). Wall and Marsh (1988) reported that within-pedon variability is low (CVs $<10 \%)$ for $\mathrm{Sr}$, Co, and $\mathrm{Li}$, intermediate $(10 \%<\mathrm{CVs}<20 \%)$ for $\mathrm{Ni}, \mathrm{Mn}, \mathrm{Pb}$, and $\mathrm{Cr}$, and high (CVs $>20 \%)$ for $\mathrm{Cu}$ and $\mathrm{Zn}$ contents, and the variability of $\mathrm{Cu}$, $\mathrm{Sr}, \mathrm{Co}, \mathrm{Ni}, \mathrm{Pb}$, and $\mathrm{Li}$ contents are not related to horizon type, drainage, or parent materials. The Fe content and magnetic susceptibility varied within-pedons from tropical regions (Curi et al., 2017; Ribeiro et al., 2017; Silva et al., 2018b). 
Soil variation consists of systematic variation that can be explained and random variation (noise) that is unsolved, and the variation is scaledependent (Burrough, 1983). Short-range variation is defined as the variation of soils or soil properties including horizonation within a few meters. The variation of soil properties usually increases with the increasing scale from pedons to polypedons to mapping units (Patterson and Wall, 1982), but the variation within a few square meters may be considerable. Beckett and Webster (1971) showed that up to half of the variation of a field may occur within any square meter of it. Christensen and Malmros (1982) calculated CVs within a sample (analytical error), CVs of replicate samples (variation within $1 \mathrm{~m}^{2}$ ), and $\mathrm{CVs}$ of 10 soil profiles (variation within a $50 \times 50 \mathrm{~m}$ experimental plot) of loss-on-ignition and carbon content. They found that the analytical error is very low $(\mathrm{CV}<3 \%)$, and the variation within $1 \mathrm{~m}^{2}$ is approximately $30 \%$ of the variation within the plot. Stark et al. (2004) compared the variability of two sites, three locations within each site, and 10 samples within each location (samples collected within a $25-\mathrm{cm}$ radius circle) for biotic and abiotic properties. They found that $\mathrm{CVs}$ for biotic properties (microbial biomass $\mathrm{C}$ and $\mathrm{N}$ ) at each location $\left(0.2 \mathrm{~m}^{2}\right.$ area) were higher than those within or between sites, whereas abiotic properties (total $\mathrm{C}$ and $\mathrm{N}$ ) had higher CVs between sites than within each location. The CVs of nitrate were calculated for different sampling distances in Fig. 22 with
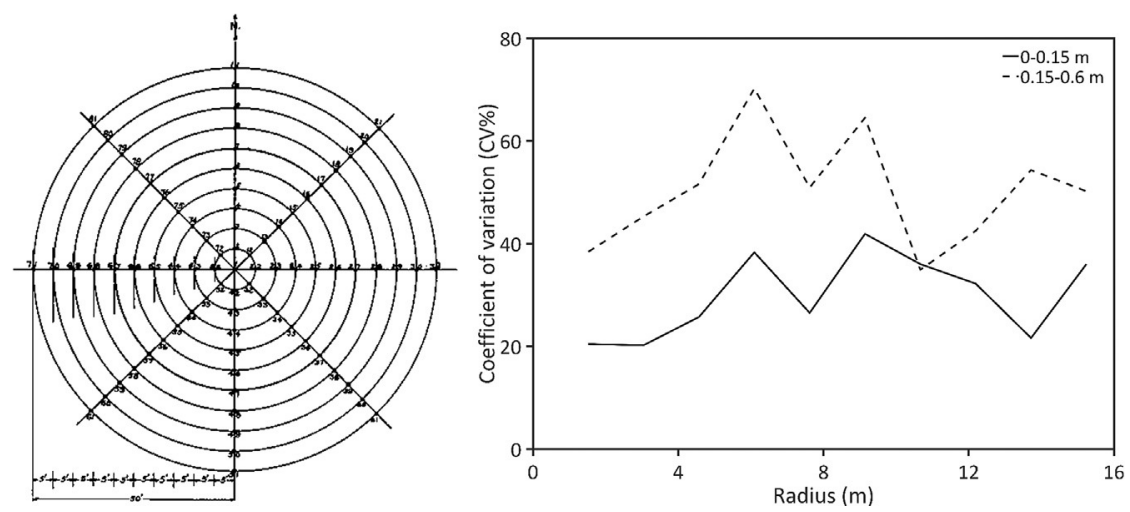

Fig. 22 Coefficients of variation (CVs\%) of nitrate at two depths $(0-0.15$ and $0.15-0.6 \mathrm{~m})$ with increasing sampling distance. The diameter of the plot in the left is $100 \mathrm{ft}(30.5 \mathrm{~m})$ and the distance increment is $5 \mathrm{ft}(1.52 \mathrm{~m})$. The figure in the left is from Waynick (1918). The CVs $(\%)$ were calculated with samples $(n=8)$ of the same radius from center. Data from Waynick, D.D., 1918. Variability in soils and its significance to past and future soil investigations. I. A statistical study of nitrification in soils, vol. 3. University of California Publications in Agricultural Sciences, pp. 243-270. 
data from Waynick (1918). The variation increased with increasing sampling distance up to $6 \mathrm{~m}$ and then varied from 6 to $15 \mathrm{~m}$.

Several studies compared spatial variation with temporal variation. Raupach (1951a) found that the seasonal variation is small compared with the spatial variation even over small areas. Ball and Williams (1968) compared the CVs of bulk samples (single large sample: $30 \times 30 \times 15 \mathrm{~cm} ; 22$ subsamples analyzed), replicate samples (22 samples collected within a circle of $0.75 \mathrm{~m}$ radius), and seasonal samples (collected once a week for 22 weeks) in A horizons of three soil profiles for several properties ( $\mathrm{pH}$, loss-on-ignition, extractable $\mathrm{P}_{2} \mathrm{O}_{5}$, exchangeable cations: $\mathrm{K}, \mathrm{Na}, \mathrm{Ca}, \mathrm{Mg}, \mathrm{Mn}$ ). They found that the CVs of bulk samples were smaller than those of replicate samples, especially for exchangeable cations, whereas replicate samples were approximately equal to the CVs of the seasonal samples.

\subsection{Horizon boundaries}

Soil horizon boundaries are often wavy and of variable thickness (e.g., Figs. 10 and 12) (Lyford, 1939; Vazhenin et al., 1969). Sidorova and Krasilnikov (2008) investigated three sites under the forest with Spodosols, soils with aquic moisture regimes (Gleysols), Histosols, Entisols, and Alfisols. They found that the thicknesses of all soil horizons were highly variable and that the variation increased in the sequence of horizons $\mathrm{B} \rightarrow \mathrm{O} \rightarrow \mathrm{E} \rightarrow \mathrm{A}$. Liski (1995) studied the $\mathrm{O}$ and $\mathrm{E}$ horizons of Spodosols in Finland and found a CV of $25 \%$ for O horizon thickness and $76 \%$ for $\mathrm{E}$ horizon thickness. Horizon thickness was strongly related to landscape position. Bailey et al. (2014) found that the formation and distribution of $\mathrm{Oa} / \mathrm{A}, \mathrm{E}, \mathrm{Bhs}, \mathrm{Bs}$, and Bh horizons of Spodosols in a catchment reflected the landscape positions and the influence of the water table. Another study of Spodosols found that the thickness of the B horizon was the highest in the soils at the footslope position due to deposition, and the lowest in the soil at the backslope position (Zebarth et al., 2002). Seelig et al. (1990) studied three soil trenches $(1 \mathrm{~m}$ deep $\times 10 \mathrm{~m}$ wide) at different landscape positions (upland, intermediate, and lower). They found a higher morphologic variation on the upland position but lower variation at the lower positions with poorly drained soils.

Horizon thickness does not seem to affect the variation of soil properties within each horizon, i.e., thicker horizons do not necessarily have higher variation of soil properties. The relationship between $\mathrm{CV}$ s and horizon thickness is presented in Fig. 23 for A and B horizons (data compiled from the literature). In the A horizon, the variations (CVs) of soil properties were 

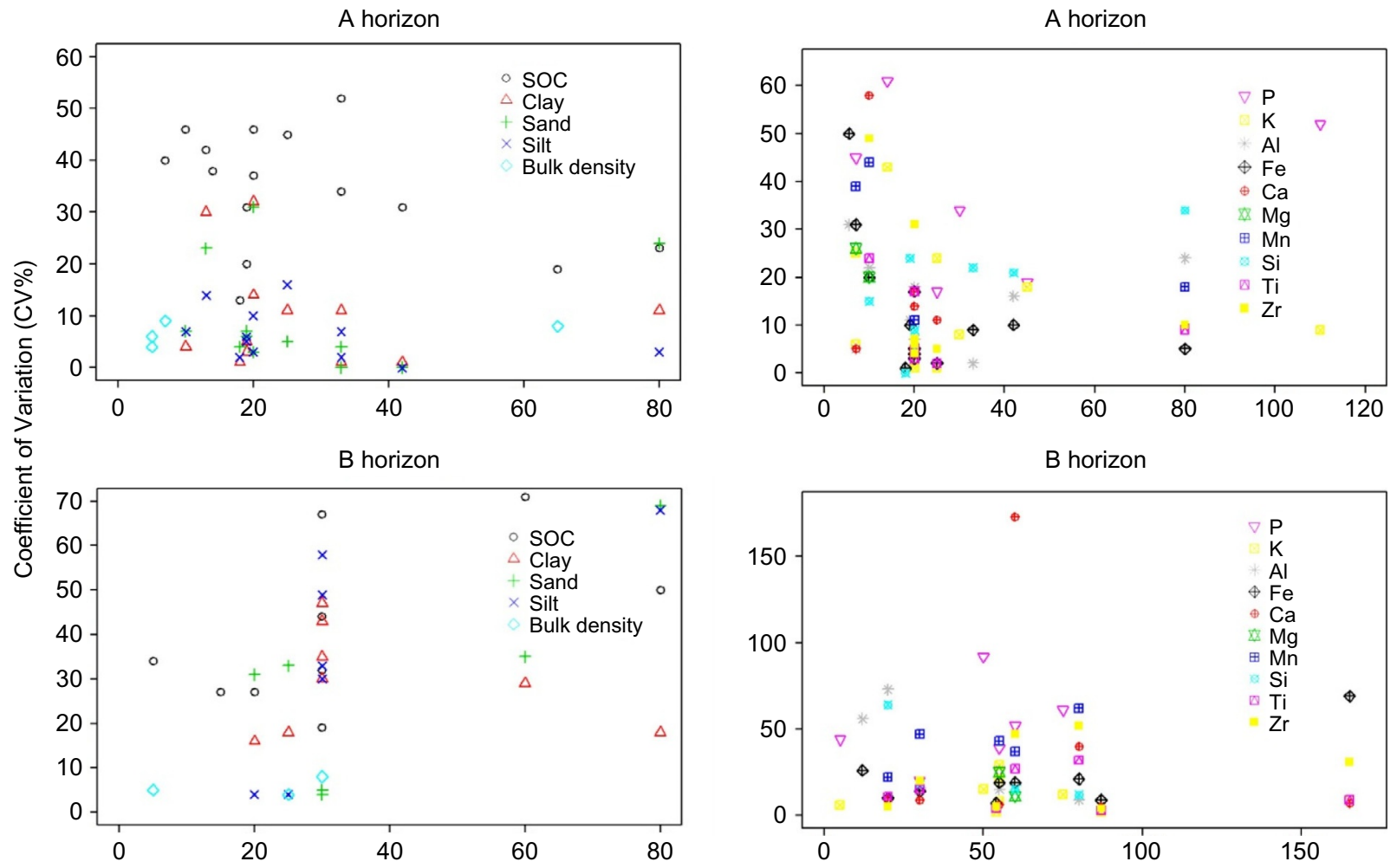

Thickness $(\mathrm{cm})$

Fig. 23 Comparison of coefficients of variation (CVs\%) of soil properties with horizon thickness for A and B horizons of different soils. Data are from studies in Table 4. 
not correlated with the horizon thickness. In the B horizon, the variation of several soil properties (sand, silt, bulk density, Fe, and Mn) were slightly positively correlated with horizon thickness, whereas the variation of $\mathrm{Al}$ and $\mathrm{Si}$ were slightly negatively correlated with horizon thickness.

\subsection{Implications for soil sampling}

Errors from laboratory analyses are often low compared to errors from wrongly sampling the soil in the field (Reed and Rigney, 1947). Several studies have found considerable short-range and within-horizon variation and concluded that sampling a single core is not enough. Ball and Williams (1968) observed high variation over distances of centimeters and meters in uncultivated soils. Burrough (1983) used the fractal method and Hausdorff-Besicovitch dimension as a measure of the relative balance between long- and short-range variations. He found that the soil data had a much higher short-range variation than landform or groundwater surfaces, and concluded that observations from single $10-\mathrm{cm}$ core or auger are unsatisfactory. Zhang and Hartemink (2017) found large horizontal variation in quantifying SOC stock of a soil profile (within 1-m distance) using a single core. Bulk density measurements for organic horizons may have considerable variation partly due to the errors in the process of collecting undisturbed samples of fibrous material. Therefore, several cores within short distance should be collected for capturing the short-range variation of soil properties. Smeck and Wilding (1980) presented several multi-core sampling schemes for sampling a pedon (Fig. 24); other schemes were provided by Oliver and Webster (1986).

A composite sample (mixed from three to five subsamples) is generally recommended for estimating soil properties within a pedon (Palmer et al., 2005; Patterson and Wall, 1982). The number of replicate lateral samples needed to estimate the mean content of an element is determined by the element under consideration, parent materials, and desired accuracy of the mean estimate (Drees and Wilding, 1973). Drees and Wilding (1973) found that three samples within each horizon are needed to estimate the mean with $\pm 10 \%$ uncertainty for soils developed from loess and till, but 20 samples are needed to achieve the same accuracy for soils developed from outwash deposit. Armson (1977) provided a table in the appendix of his book on forest soils that shows the number of samples necessary to achieve a $90 \%$ probability in accuracy of soil property. Bulking samples can decrease the errors 


\section{PEDON SAMPLING SCHEMES}

Pedon Area $1-10 \mathrm{~m}^{2}$

Pedon Sampling Interval $1 / 3-1 / 2 \mathrm{~m}$

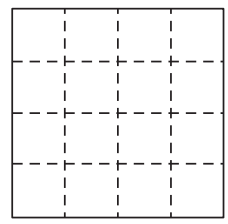

Grid

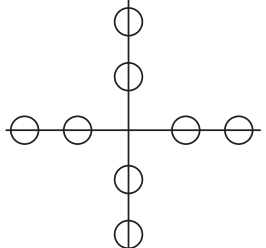

Cross

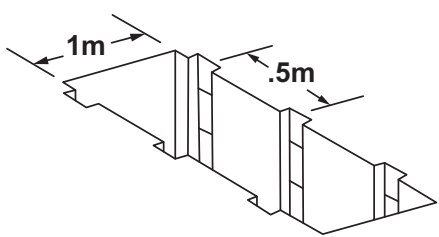

Pit Face

Fig. 24 Sub-sampling schemes for sampling pedons. From Smeck, N.E., Wilding, L.P., 1980. Quantitative evaluation of pedon formation in calcareous glacial deposits in Ohio. Geoderma 24, 1-16.

resulting from microvariation (Vazhenin et al., 1969) and provide a reliable mean estimate with certain confidence but fails to provide information on the variability within the site (Ball and Williams, 1968).

Higher sampling intensity often increases the estimation accuracy. Wall and Marsh (1988) found that greater sampling intensity resulted in smaller CVs. Vazhenin et al. (1969) reported that more samples should be taken from the upper horizons than the lower horizons since they observed larger variation at the top of the soil profile (e.g., SOC content). Several sampling designs have been proposed for estimating profile SOC stocks (Zhang and Hartemink, 2017), showing that color information or spectra can be used to represent the variation of the soil profile and improve the estimates.

\subsection{Depth functions}

Soil varies continuously with depth, and naturally every soil property has its specific depth function (Jenny, 1941). SOC concentration usually decreases with depth except in Spodosols, some sodic soils, and soils with relict second humus horizons (Demchenko et al., 2008), including Andisols containing vertical sequences of organic matter-rich buried soil horizons on successions of tephra layers (e.g., Fig. 7; Birrell and Pullar, 1973; Inoue et al., 2011). The depth function for SOC concentration has often been modeled by an exponential decay function (Minasny et al., 2006). A power function has also 
been used to illustrate the decreasing pattern of SOC with depth (Liu et al., 2016). The topsoil has a higher concentration of SOC and a higher variation of SOC. Zhang et al. (2017) used a sigmoid function to represent the vertical distribution of soil $\mathrm{pH}$. They found that the topsoil (A horizon) and deep soil (C horizon) were uniform due to the cultivation and groundwater movement, whereas the subsoil (B horizon) was a transitional horizon for $\mathrm{pH}$ and had relatively high variation. Myers et al. (2011) used a peak function to fit the vertical distribution of clay, silt, and $\mathrm{pH}$ in a clay-pan soil landscape. They found higher variation in the subsoil where the clay-pan was present. Equal area quadratic spline functions with flexible shape have been used to model the vertical distribution of various soil properties (Bishop et al., 1999).

Minasny et al. (2016) identified seven types of depth functions: uniform, gradational, exponential, wetting front, abrupt, peak, and minima-maxima. The uniform and gradational functions showed uniform lateral variation with depth and exponential function showed higher variation in the topsoil, whereas the other functions showed higher variation in the subsoil. Depth functions illustrate the vertical distribution of soil properties and show change with depth but do not show the horizontal variation of soil properties.

\subsection{Improved soil horizon delineation}

Digital soil morphometrics is defined as using tools or techniques to measure and quantify soil profile attributes with the purpose of increasing pedological understanding (Hartemink and Minasny, 2014). The development of proximal soil sensing techniques and profile mapping methods promotes the quantification of two-dimensional soil profile properties and variation (Fig. 25). Soil proximal sensing technique (pXRF) has been used to characterize the mineralogy of sand, silt, and clay fractions of an Inceptisol profile in Brazil (Silva et al., 2018a). Imaging spectroscopy and regression methods have been used to map SOC, elemental concentration, and diagnostic horizons of an Alfisol (Steffens and Buddenbaum, 2013) and an Entisol (Schreiner et al., 2015). Wu et al. (2018) mapped the salt content in the soil profile $(0.3-\mathrm{m}$ wide $\times 1-\mathrm{m}$ deep) under field conditions using vis-NIR hyperspectral imaging and machine learning methods. Roudier et al. (2016) mapped the first three principal components of visNIR spectra of soil monoliths using digital images and regression kriging. 
A Profile mapping with laboratory imaging spectroscopy in Steffens and Buddenbaum (2013)
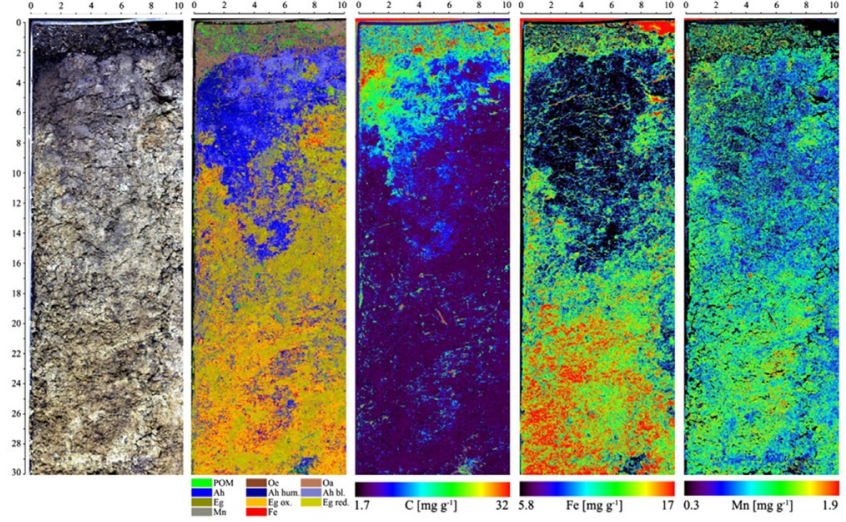

B Monolith scanning and mapping in Roudier et al. (2016)
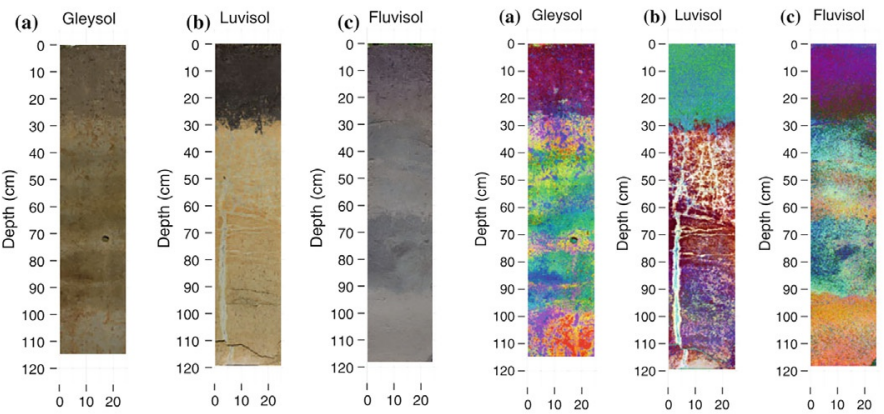

C Profile mapping with digital camera in Zhang and Hartemink (2019a)
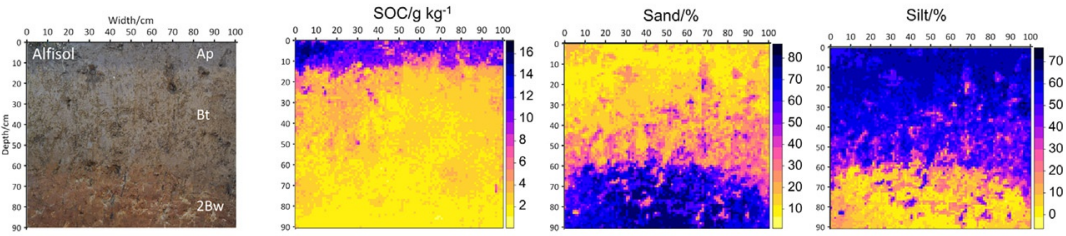

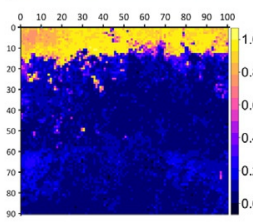

Cluster 1

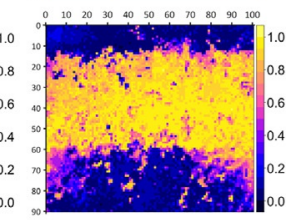

Cluster 2

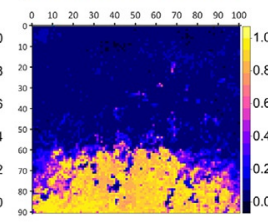

Cluster 3

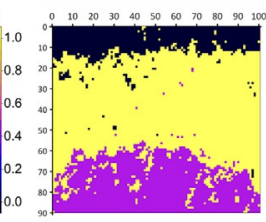

Hard clustering

Fig. 25 Digital soil morphometrics approach to investigate soil profile variations. 
Zhang and Hartemink (2019a) used color models extracted from a digital image and regression kriging to map SOC, texture, and weathering indices in an Alfisol. Block kriging was used to map SOC, pH, and elemental concentrations in a Mollisol (Grauer-Gray and Hartemink, 2016) and an Entisol (Adhikari et al., 2016). The profile maps showed substantial variation in the soil profiles. Compared with machine learning methods for high-resolution profile mapping, interpolation methods (e.g., block kriging) reduced the fine-scale variation and displayed more smoothing of variation in the soil profiles.

Several studies have attempted to use the predicted profile maps of soil properties for horizon delineation. Adhikari et al. (2016) used $k$-means clustering on profile maps of $\mathrm{Al}, \mathrm{Si}, \mathrm{Fe}, \mathrm{Mn}, \mathrm{Ca}$, and the red color coordinate of an Entisol profile and obtained three layers which were similar to the field-delineated horizons. Roudier et al. (2016) used hierarchical classification on profile maps and obtained six classes. Steffens and Buddenbaum (2013) used supervised classification to create a profile classification map of 11 classes (including particulate organic matter (POM), O, A, and E horizons, Mn, and Fe). Zhang and Hartemink (2019a) used fuzzy c-means on profile maps of SOC, texture, and weathering indices and obtained three clusters with confusion index maps showing the wavy horizon boundaries and impurity within horizons. Profile maps and classification maps have shown a considerable variation of soil profiles and within horizons. Fajardo et al. (2016) used intraclass correlation (ICC) to measure the homogeneity of spectrally derived horizons on one-dimensional soil cores. Zhang and Hartemink (2019b) used an automated horizonation method to directly identify soil horizons on soil profile images and found considerable impurity of identified horizons in the clustering maps.

Soil horizons are often distinguished by using differences in color, texture, structure, coarse fragments, and mottles and other redoximorphic features. Only a few studies have investigated the variation of structure, coarse fragments, and mottles. Hirmas et al. (2016) used three-dimensional laser scanning to quantify the soil structure and porosity. Mohammed et al. (2016) used digital photography to quantify ped shapes. O'Donnell et al. (2010) used feature selection to identify and quantify soil redoximorphic features on digital images of soil cores. Wang et al. (2017) quantified the krotovinas of an Alfisol with image analysis and studied their distribution across the two-dimensional profile wall. Future work should quantify the structure, coarse fragments, and mottles of soil profiles and investigate the variation between and within each horizon. 


\section{Conclusions}

We have reviewed soil horizon variation for the master horizons grouped by Soil Taxonomy soil orders. The following is concluded:

- Within-horizon variation varies with depth and such variation differs for different soil properties. The $\mathrm{B}$ and $\mathrm{C}$ horizons had higher variation than the A horizons for SOC and texture, whereas the variation of the elemental concentrations was higher in the $\mathrm{A}$ and $\mathrm{B}$ horizons than in the C horizons.

- Several factors affect the variation within horizons, including landscape position, parent material, vegetation, fertilization, tillage, drainage, and time. The variation in soil horizons varies among soils.

- Soil horizon variation is scale-dependent. The variation of soil properties usually increases from pedons to polypedons to mapping units, but the variation within a few square meters may be considerable.

- Variation may be substantial within soil profiles and horizons, and it has implication for soil processes as well as soil management. Soil horizon variation influences the hydraulic properties of soil (Samouelian et al., 2011), water and solutes transportation within the soil profile (Deurer et al., 2003), plant nutrition availability (Göttlein and Matzner, 1997), root growth and distribution (Parker and Van Lear, 1996), and microbial communities within the soil profile (Hansel et al., 2008).

- Highly weathered soils in tropical regions have been considered morphologically homogeneous within horizons, between horizons, and across the landscape. Using proximal sensors, including portable X-ray fluorescence spectrometer, it has been found that these soils may contain more variation than was assumed.

- The variation in soil horizons varies among soil orders although soil horizon variation has not been systematically studied in all soil orders. Most studies on soil horizon variation have been conducted in Alfisols and Spodosols. Variations within Gelisol horizons have been studied in relation to cryoturbation features. Spodosol profiles showed greater microvariation than the Mollisol profiles, and Oxisols showed relatively low variations.

- Several studies have presented considerable short-range variation and within-horizon variation and have stated that a single core sampling is not enough. Several soil cores within a short distance or a composite sample should be collected to capture the short-range variation. 
- The development of proximal soil sensing techniques and profile mapping methods promotes the quantification of soil profile variation and automated soil horizon delineation.

\section{Acknowledgments}

We are deeply thankful to all the soil profiles that we have seen over the years; they have puzzled us, amazed us, and kept us thinking. These little wounds in the Earth's skin have told us stories and gave us insight about the past, present, and future of our planet and its inhabitants. Soil horizons have been a major inspiration to all of us, as we continue to unravel the patterns from their character and variation.

The review of the Russian literature and the landscape-scale case study were prepared with the support of the Russian Science Foundation, project No. 17-17-01293. The authors thank Dr. Valeria Sidorova for her contribution to the case study on landscape-scale horizon variability.

\section{References}

Adhikari, K., Hartemink, A.E., Minasny, B., 2016. Mapping a profile wall of a typic udipsamments from the central sands in Wisconsin, USA. In: Hartemink, A.E., Minasny, B. (Eds.), Digital Soil Morphometrics. Springer International Publishing, Dordrecht, pp. 191-206.

Almond, P.C., Tonkin, P.J., 1999. Pedogenesis by upbuilding in an extreme leaching and weathering environment, and slow loess accretion, south Westland, New Zealand. Geoderma 92, 1-36.

Alway, F., Trumbull, R., 1912. On the sampling of prairie soils. In: 25th Annual Report of the Nebraska Agricultural Experiment Station, pp. 25-51.

Armson, K.A., 1977. Forest Soils: Properties and Processes. University of Toronto Press, Canada. 390 pp.

Arnold, R., Eswaran, H., 1993. Soil horizon use by the US Soil Survey. Catena 20, 375-381.

Bailey, S.W., Brousseau, P.A., McGuire, K.J., Ross, D.S., 2014. Influence of landscape position and transient water table on soil development and carbon distribution in a steep, headwater catchment. Geoderma 226-227, 279-289.

Baldwin, M., Kellogg, C.E., Thorp, J., 1938. Soil classification. In: Soils and Men, U.S. Department of Agriculture Yearbook. U.S. Government Printing Office, Washington, DC, pp. 979-1001.

Ball, D., Williams, W., 1968. Variability of soil chemical properties in two uncultivated brown earths. Eur. J. Soil Sci. 19, 379-391.

Beckett, P., 1967. Lateral changes in soil variability. J. Aust. Inst. Agric. Sci. 33, 172-179.

Beckett, P.H.T., Webster, R., 1971. Soil variability—a review. Soils Fertil. 33, 203-217.

Birkeland, P.W., 1999. Soils and Geomorphology, third ed. Oxford University Press, New York.

Birrell, K.S., Pullar, W.A., 1973. Weathering of paleosols in Holocene and late Pleistocene tephras in central North Island, New Zealand. N. Z. J. Geol. Geophys. 16, 687-702.

Bishop, T.F.A., McBratney, A.B., Laslett, G.M., 1999. Modelling soil attribute depth functions with equal-area quadratic smoothing splines. Geoderma 91, 27-45.

Blagoveshchenskii, Y.N., Samsonova, V.P., 2001. The fractal dimension index as applied to the description of the variable thickness of humus horizons on dumps of various ages. Eurasian Soil Sci. 34, 479-483.

Bockheim, J.G., 2007. Importance of cryoturbation in redistributing organic carbon in permafrost-affected soils. Soil Sci. Soc. Am. J. 71, 1335-1342. 
Bockheim, J.G., 2016. Classification and distribution of soils with albic horizons in the USA: a preliminary analysis. Geoderma 262, 85-93.

Bockheim, J.G., 2018. Diversity of diagnostic horizons in soils of the contiguous USA: a case study. Catena 168, 5-13.

Bockheim, J.G., Gennadiyev, A.N., 2000. The role of soil-forming processes in the definition of taxa in Soil Taxonomy and the World Soil Reference Base. Geoderma 95, 53-72.

Bockheim, J.G., Tarnocai, C., 1998. Recognition of cryoturbation for classifying permafrost-affected soils. Geoderma 81, 281-293.

Bockheim, J.G., Everett, L.R., Hinkel, K.M., Nelson, F.E., Brown, J., 1999. Soil organic carbon storage and distribution in arctic tundra, Barrow, Alaska. Soil Sci. Soc. Am. J. 63, 934-940.

Bockheim, J.G., Hinkel, K.M., Eisner, W.R., Dai, X.Y., 2004. Carbon pools and accumulation rates in an age-series of soils in drained thaw-lake basins, arctic Alaska. Soil Sci. Soc. Am. J. 68, 697-704.

Bockheim, J., Gennadiyev, A., Hammer, R., Tandarich, J., 2005. Historical development of key concepts in pedology. Geoderma 124, 23-36.

Boone, R.D., Grigal, D.F., Sollins, P., Ahrens, R.J., Armstrong, D.E., 1999. Soil Sampling, Preparation, Archiving, and Quality Control. Oxford University Press, New York.

Brevik, E.C., Hartemink, A.E., 2010. Early soil knowledge and the birth and development of soil science. Catena 83, 23-33.

Bridges, E.M., 1993. Soil horizon designations; past use and future prospects. Catena 20, 363-373.

Burrough, P.A., 1983. Multiscale sources of spatial variation in soil. I. The application of fractal concepts to nested levels of soil variation. J. Soil Sci. 34, 577-597.

Christensen, B.T., Malmros, P.A., 1982. Loss-on-ignition and carbon content in a beech forest soil profile. Ecography 5, 376-380.

Churchman, G.J., 2010. The philosophical status of soil science. Geoderma 157, 214-221.

Churchman, G.J., Lowe, D.J., 2012. Alteration, formation, and occurrence of minerals in soils. In: Huang, P.M., Li, Y., Sumner, M.E. (Eds.), Handbook of Soil Sciences, second ed. Properties and Processes, vol. 1. CRC Press, Boca Raton, pp. 20.1-20.72.

Churchward, H.M., 1961. Soil studies at Swan Hill, Victoria, Australia I. Soil layering. J. Soil Sci. 12, 73-86.

Clayden, B., Hewitt, A.E., 1989. Horizon notation for New Zealand soils Division of Land and Soil Sciences Scientific Report 1. 30 pp.

Cline, M.G., 1944. Principles of soil sampling. Soil Sci. 58, 275-288.

Curi, N., Silva, S.H.G., Poggere, G.C., de Menezes, M.D., 2017. Soil Mapping and Magnetism at UFLA as Environmental Tracers, first ed. Editora UFLA, Lavras.

Dahlgren, R.A., Saigusa, M., Ugolini, F.C., 2004. The nature, properties and management of volcanic soils. Adv. Agron. 82, 113-182.

de Gruijter, J., Brus, D.J., Bierkens, M.F., Knotters, M., 2006. Sampling for Natural Resource Monitoring. Springer Science \& Business Media.

Demchenko, P.F., Shein, E.V., Golitsyn, G.S., 2008. Estimates of spatial spectra of specific physical parameters of soils based on experimental data. Dokl. Earth Sci. 421, 954-956.

Deurer, M., Duijnisveld, W.H.M., Böttcher, J., 2000. Spatial analysis of water characteristic functions in a sandy podzol under pine forest. Water Resour. Res. 36, 2925-2935.

Deurer, M., Green, S.R., Clothier, B.E., Böttcher, J., Duijnisveld, W.H.M., 2003. Drainage networks in soils. A concept to describe bypass-flow pathways. J. Hydrol. 272, 148-162.

Dmitriev, E.A., 1983. Soil horizons. Soviet Soil Sci. 15, 62-70.

Dmitriev, E.A., Karpachevsky, L.O., Sapozhnikov, P.M., 1981. Some physical properties of morphons and morphological elements of soddy podzolic soils. Soviet Soil Sci. $13,75-85$. 
Drees, L.R., Wilding, L.P., 1973. Elemental variability within a sampling unit. Soil Sci. Soc. Am. J. 37, 82-87.

Duchaufour, P., 1977. Pédologie. In: Pédogenèse et Classification. Tome IMasson, Paris, 477 pp (In French).

Fajardo, M., McBratney, A., Whelan, B., 2016. Fuzzy clustering of Vis-NIR spectra for the objective recognition of soil morphological horizons in soil profiles. Geoderma 263, 244-253.

FitzPatrick, E.A., 1993. Principles of soil horizon definition and classification. Catena 20, 395-402.

Gallagher, P., Herlihy, M., 1963. An evaluation of errors associated with soil testing. Ir. J. Agric. Res. 2, 149-167.

Gerasimova, M.I., Lebedeva, I.I., Khitrov, N.B., 2013. Soil horizon designation: state of the art, problems, and proposals. Eurasian Soil Sci. 46, 599-609.

Göttlein, A., Matzner, E., 1997. Microscale heterogeneity of acidity related stress-parameters in the soil solution of a forested cambic podzol. Plant Soil 192, 95-105.

Göttlein, A., Stanjek, H., 1996. Micro-scale variation of solid-phase properties and soil solution chemistry in a forest podzol and its relation to soil horizons. Eur. J. Soil Sci. 47, 627-636.

Gough, L., Shaver, G.R., Carroll, J., Royer, D.L., Laundre, J.A., 2000. Vascular plant species richness in Alaskan arctic tundra: the importance of soil pH. J. Ecol. 88, 54-66.

Grange, L.I., Taylor, N.H., 1932. The occurrence of bush sickness on the volcanic soils of the North Island. A. The distribution and field characteristics of bush-sick soils. N. Z. Dep. Sci. Ind. Res. Bull. 32, 21-35.

Grauer-Gray, J.R., Hartemink, A.E., 2016. Variation of soil properties in a Mollisol profile wall. In: Hartemink, A.E., Minasny, B. (Eds.), Digital Soil Morphometrics. Springer International Publishing, Dordrecht, pp. 165-189.

Grauer-Gray, J., Hartemink, A.E., 2018. Raster sampling of soil profiles. Geoderma 318, 99-108.

Hansel, C.M., Fendorf, S., Jardine, P.M., Francis, C.A., 2008. Changes in bacterial and archaeal community structure and functional diversity along a geochemically variable soil profile. Appl. Environ. Microbiol. 74, 1620-1633.

Hartemink, A.E., 2009. The depiction of soil profiles since the late 1700s. Catena 79, 113-127.

Hartemink, A.E., 2015. The use of soil classification in journal papers between 1975 and 2014. Geoderma Reg. 5, 127-139.

Hartemink, A.E., Minasny, B., 2014. Towards digital soil morphometrics. Geoderma 230, 305-317.

Hartemink, A.E., Gennadiyev, A.N., Bockheim, J.G., Bero, N., 2017. Short-range variation in a Wisconsin soilscape (USA). Eurasian Soil Sci. 50, 198-209.

Hirmas, D.R., Giménez, D., Mome Filho, E.A., Patterson, M., Drager, K., Platt, B.F., Eck, D.V., 2016. Quantifying soil structure and porosity using three-dimensional laser scanning. In: Hartemink, A.E., Minasny, B. (Eds.), Digital Soil Morphometrics. Springer International Publishing, Dordrecht, pp. 19-35.

Hole, F.D., 1961. A classification of pedoturbations and some of other processes and factors of soil formation in relation to isotropism and anisotropism. Soil Sci. 91, 375-377.

Inoue, Y., Nagaoka, S., Sugiyama, S., 2011. Late Pleistocene buried humic soils within a tephra-soil sequence near Unzen volcano, Kyushu, Japan. Quat. Int. 246, 233-238.

IUSS Working Group WRB, 2015. World Reference Base for Soil Resources 2014: International Soil Classification System for Naming Soils and Creating Legends for Soil Maps. Food and Agriculture Organization of the United Nations, Rome, Italy. 
Jenny, H., 1941. Factors of Soil Formation: A System of Quantitative Pedology. McGrawHill.

Joffe, J.S., 1929. Soil profile studies: I. Soil as an independent body and soil morphology. Soil Sci. 28, 39-54.

Johnson, D.L., Watson-Stegner, D., 1987. Evolution model of pedogenesis. Soil Sci. 143, 349-366.

Johnson, D.L., Watson-Stegner, D., Johnson, D.N., Schaetzl, R.J., 1987. Proisotropic and proanisotropic processes of pedoturbation. Soil Sci. 143, 278-292.

Johnson, D.L., Keller, E.A., Rockwell, T.K., 1990. Dynamic pedogenesis: new views on some key soil concepts, and a model for interpreting quaternary soils. Quat. Res. 33, 306-319.

Johnson-Maynard, J.L., McDaniel, P.A., Ferguson, D.E., Falen, A.L., 1997. Chemical and mineralogical conversion of Andisols following invasion by bracken fern. Soil Sci. Soc. Am. J. 61, 549-555.

Kellogg, C.E., 1930. Preliminary study of the profiles of the principal soil types of Wisconsin. In: Wisconsin Geological and Natural History Survey. Bulletin No. 77A. Soil Series No. 54.

Kellogg, C.E., 1934. Morphology and genesis of the Solonetz soils of western North Dakota. Soil Sci. 38, 483-502.

Kellogg, C.E., 1949. Soil classification. Soil Sci. 67, 77-191.

Khitrov, N.B., 2016. Vertisols with Gilgai microtopography: classification and parameters of microtopography and morphological types of soils (a review). Eurasian Soil Sci. 49, 125-144.

Knox, E.G., 1965. Soil individuals and soil classification. Soil Sci. Soc. Am. Proc. 29, 79-84.

Kornblum, E.A., 1975. The main levels of morphological organization of soil matrix. Pochvovedenie 9, 36-48 (in Russian).

Liski, J., 1995. Variation in soil organic carbon and thickness of soil horizons within a boreal forest stand - effect of trees and implications for sampling. Silva Fennica 29, 255-266.

Liu, F., Rossiter, D.G., Song, X.-D., Zhang, G.-L., Yang, R.-M., Zhao, Y.-G., Li, D.-C., Ju, B., 2016. A similarity-based method for three-dimensional prediction of soil organic matter concentration. Geoderma 263, 254-263.

Lowe, D.J., 2019. Using soil stratigraphy and tephrochronology to understand the origin, age, and classification of a unique Late Quaternary tephra-derived Ultisol in Aotearoa New Zealand. Quaternary 2, 1-34.

Lowe, D.J., Tonkin, P.J., 2010. Unravelling upbuilding pedogenesis in tephra and loess sequences in New Zealand using tephrochronology. In: Proceedings of the 19th World Congress of Soil Science "Soil Solutions for a Changing World" (August 1-6, 2010, Brisbane), Symposium 1.3.2 Geochronological Techniques and Soil Formation, pp. 34-37. Published at http://www.iuss.org/19th\%20WCSS/Author_Main.html.

Lyford, W.H., 1939. Horizon variations of three New Hampshire Podzol profiles. Soil Sci. Soc. Am. J. 3, 242-246.

Macedo, R.S., Teixeira, W.G., Corrêa, M.M., Martins, G.C., Vidal-Torrado, P., 2017. Pedogenetic processes in anthrosols with pretic horizon (Amazonian Dark Earth) in Central Amazon, Brazil. PLoS One 12, e0178038.

Marbut, C.F., 1921. The contribution of soil surveys to soil science. In: Society for the Promotion of Agricultural Science Proceedings. 41, pp. 116-142.

Marbut, C.F., 1928. In: Weber, G.A. (Ed.), The Bureau of Chemistry and Soils: Its History, Activities, and Organization. The Brookings Institution, Washington, DC, pp. 91-98.

McBratney, A.B., 1993. Some remarks on soil horizon classes. Catena 20, 427-430.

McBratney, A.B., Mendonça Santos, M.L., Minasny, B., 2003. On digital soil mapping. Geoderma 117, 3-52. 
McCool, M.M., Veatch, J.O., Spurway, C.H., 1923. Soil profile studies in Michigan. Soil Sci. 16, 95-106.

McDaniel, P.A., Lowe, D.J., Arnalds, O., Ping, C.-L., 2012. Andisols. In: Huang, P.M., Li, Y., Sumner, M.E. (Eds.), Handbook of Soil Sciences, second ed. In: Properties and Processes, vol. 1. CRC Press, Boca Raton, pp. 33.29-33.48.

Minasny, B., McBratney, A.B., Mendonça-Santos, M.L., Odeh, I.O.A., Guyon, B., 2006. Prediction and digital mapping of soil carbon storage in the Lower Namoi Valley. Aust. J. Soil. Res. 44, 233-244.

Minasny, B., Stockmann, U., Hartemink, A.E., McBratney, A.B., 2016. Measuring and modelling soil depth functions. In: Hartemink, A.E., Minasny, B. (Eds.), Digital Soil Morphometrics. Springer International Publishing, Dordrecht, pp. 225-240.

Mohammed, A.K., Hirmas, D.R., Giménez, D., Mandel, R.D., Miller, J.R., 2016. A digital morphometric approach for quantifying ped shape. Soil Sci. Soc. Am. J. 80, 1604-1618.

Muhs, D.R., McGeehin, J.P., Beann, J., Fisher, E., 2004. Holocene loess deposition and soil formation as competing processes, Matanuska Valley, southern Alaska. Quat. Res. 61, 265-276.

Muir, J.W., 1962. The general principles of classification with reference to soils. J. Soil Sci. $13,22-30$.

Myers, D.B., Kitchen, N.R., Sudduth, K.A., Miles, R.J., Sadler, E.J., Grunwald, S., 2011. Peak functions for modeling high resolution soil profile data. Geoderma 166, 74-83.

O’Donnell, T.K., Goyne, K.W., Miles, R.J., Baffaut, C., Anderson, S.H., Sudduth, K.A., 2010. Identification and quantification of soil redoximorphic features by digital image processing. Geoderma 157, 86-96.

Oliver, M.A., Webster, R., 1986. Combining nested and linear sampling for determining the scale and form of spatial variation of regionalized variables. Geogr. Anal. 18, 227-242.

Oliver, M.A., Webster, R., 1991. How geostatistics can help you. Soil Use Manage. 7, 206-217.

Palmer, D.J., Lowe, D.J., Payn, T.W., Höck, B.K., McLay, C.D.A., Kimberley, M.O., 2005. Soil and foliar phosphorus as indicators of sustainability for Pinus radiata plantation forestry in New Zealand. For. Ecol. Manage. 220, 140-154.

Papadakis, J., 1964. Soils of the World. Elsevier, Argentina, Buenos Aires.

Parker, M., Van Lear, D., 1996. Soil heterogeneity and root distribution of mature loblolly pine stands in piedmont soils. Soil Sci. Soc. Am. J. 60, 1920-1925.

Patterson, G.T., Wall, G.J., 1982. Within-pedon variability in soil properties. Can. J. Soil Sci. 62, 631-639.

Phillips, J.D., 1993. Progressive and regressive pedogenesis and complex soil evolution. Quat. Res. 40, 169-176.

Ping, C.-L., Clark, M.H., Kimble, J.M., Michaelson, G.J., Shur, Y., Stiles, C.A., 2013. Sampling protocols for permafrost-affected soils. Soil Horiz. 54, 13-19.

Purvis, E.R., Davidson, O.W., 1948. Review of the relation of calcium to availability and absorption of certain trace elements by plants. Soil Sci. 65, 111-116.

Ramenskiy, L.G., 1938. Introduction to Complex Soil-Geobotanical Study of Lands. Selhozgiz, Moscow. 620 pp. (in Russian).

Raupach, M., 1951a. Studies in the variation of soil reaction. II. Seasonal variations at Barooga, NSW. Aust. J. Agric. Res. 2, 73-82.

Raupach, M., 1951b. Studies in the variation of soil reaction. III. Variations at the Waite Agricultural Institute. Aust. J. Agric. Res. 2, 83-91.

Reed, J.F., Rigney, J., 1947. Soil sampling from fields of uniform and nonuniform appearance and soil types. J. Am. Soc. Agron. 39, 26-40.

Ribeiro, B.T., Silva, S.H.G., Silva, E.A., Guilherme, L.R.G., 2017. Portable X-ray fluorescence (pXRF) applications in tropical soil science. Cienc. Agrotecnol. 41, 245-254.

Rice, T.D., 1928. What is a soil series? Soil Sci. Soc. Am. J. B9, 125-130. 
Robinson, G.W., Lloyd, W., 1915. On the probable error of sampling in soil surveys. J. Agric. Sci. 7, 144-153.

Roudier, P., Manderson, A., Hedley, C., 2016. Advances towards quantitative assessments of soil profile properties. In: Hartemink, A.E., Minasny, B. (Eds.), Digital Soil Morphometrics. Springer International Publishing, Dordrecht, pp. 113-132.

Samouelian, A., Cousin, I., Dages, C., Frison, A., Richard, G., 2011. Determining the effective hydraulic properties of a highly heterogeneous soil horizon. Vadose Zone J. 10, 450-458.

Sanborn, P., Pawluk, S., 1989. Microstructure diversity in Ah horizons of black chernozemic soils, Alberta and British Columbia (Canada). Geoderma 45, 221-240.

Schaetzl, R.J., Follmer, L.R., 1990. Longevity of treethrow microtopography: implications for mass wasting. Geomorphology 3, 113-123.

Schaetzl, R.J., Harris, W., 2012. Spodosols. In: Huang, P.M., Li, Y., Summner, M.E. (Eds.), Handbook of Soil Sciences, second ed. In: vol. 1. CRC Press, Boca Raton, pp. 33.113-33.127. Properties and Process.

Schaetzl, R.J., Mokma, D.L., 1988. A numerical index of podzol and podzolic soil development. Phys. Geogr. 9, 232-246.

Schelling, J., 1970. Soil genesis, soil classification and soil survey. Geoderma 4, 165-193.

Schreiner, S., Buddenbaum, H., Emmerling, C., Steffens, M., 2015. VNIR/SWIR laboratory imaging spectroscopy for wall-to-wall mapping of elemental concentrations in soil cores. Photogramm. Fernerkun. Geoinf. 2015, 423-435.

Seelig, B., Richardson, J., Heidt, C., 1990. Sodic soil spatial variability and classification in coarse-loamy till of central North Dakota. Soil Horiz. 31, 33-43.

Shaw, C.F., 1928. A glossary of soil terms. Soil Sci. Soc. Am. J. B9, 23-58.

Sidorova, V.A., 2016. Dynamics of the spatial variability of soil properties of grassland agrocoenosis of Karelia during post-anthropogenic development. Russ. J. Appl. Ecol. 3, 23-27 (in Russian).

Sidorova, V.A., Krasilnikov, P.V., 2007. Soil-geographic interpretation of spatial variability in the chemical and physical properties of topsoil horizons in the steppe zone. Eurasian Soil Sci. 40, 1042-1051.

Sidorova, V., Krasilnikov, P., 2008. The use of geostatistical methods for mapping soil horizons. In: Krasilnikov, P., Carré, F., Montanarella, L. (Eds.), Soil Geography and Geostatistics: Concepts and Applications. European Commission, Joint Research Center, Luxembourg, pp. 85-106.

Sidorova, V.A., Svyatova, E.N., Tseits, M.A., 2015. Spatial variability of the properties of marsh soils and their impact on vegetation. Eurasian Soil Sci. 48, 223-230.

Silva, S.H.G., Poggere, G.C., Menezes, M.D., Carvalho, G.S., Guilherme, L.R.G., Curi, N., 2016. Proximal sensing and digital terrain models applied to digital soil mapping and modeling of Brazilian Latosols (Oxisols). Remote Sens. (Basel) 8, 614-635.

Silva, S.H.G., Hartemink, A.E., dos Teixeira, A.F.S., Inda, A.V., Guilherme, L.R.G., Curi, N., 2018a. Soil weathering analysis using a portable X-ray fluorescence (PXRF) spectrometer in an Inceptisol from the Brazilian Cerrado. Appl. Clay Sci. 162, 27-37.

Silva, S.H.G., Silva, E.A., Poggere, G.C., Guilherme, L.R.G., Curi, N., 2018b. Tropical soils characterization at low cost and time using portable X-ray fluorescence spectrometer (pXRF): effects of different sample preparation methods. Cienc. Agrotecnol. 42, 80-92.

Simonson, R.W., 1959. Outline of a generalized theory of soil genesis. Soil Sci. Soc. Am. J. 23, 152-156.

Simonson, R.W., 1962. Soil classification in the United States. Classification of soils at any point in history largely reflects current understanding of soil genesis. Science 137, 1027-1034.

Simonson, R.W., 1968. Concept of soil. Adv. Agron. 20, 1-47. 
Smeck, N.E., Wilding, L.P., 1980. Quantitative evaluation of pedon formation in calcareous glacial deposits in Ohio. Geoderma 24, 1-16.

Smith, G.D., 1960. A new soil classification scheme progress report. In: 7th International Congress of Soil Science. International Society of Soil Science, Madison, WI, p. 105.

Soil Classification Working Group, 1998. The Canadian System of Soil Classification, third ed. Agriculture and Agri-Food Canada Publication 1646. 187 pp.

Soil Science Division Staff, 2017. Soil survey manual. In: Ditzler, C., Scheffe, K., Monger, H.C. (Eds.), USDA Handbook 18. Government Printing Office, Washington, DC.

Soil Survey Staff, 1999. Soil Taxonomy: A Basic System of Soil Classification for Making and Interpreting Soil Surveys, second ed. USDA-Natural Resources Conservation Service, Washington, DC.

Soil Survey Staff, 2014. Keys to Soil Taxonomy, 12th ed. USDA-Natural Resources Conservation Service, Washington, DC.

Solomatova, E., Sidorova, V., 2008. Spatial variability of forest litters in bilberry spruce forests of Fennoscandia. In: Krasilnikov, P., Carré, F., Montanarella, L. (Eds.), Soil Geography and Geostatistics: Concepts and Applications. European Commission, Joint Research Centre, Luxembourg, pp. 26-36.

Stark, C.H.E., Condron, L.M., Stewart, A., Di, H.J., O'Callaghan, M., 2004. Small-scale spatial variability of selected soil biological properties. Soil Biol. Biochem. 36, 601-608.

Steffens, M., Buddenbaum, H., 2013. Laboratory imaging spectroscopy of a stagnic Luvisol profile-high resolution soil characterisation, classification and mapping of elemental concentrations. Geoderma 195-196, 122-132.

Stockmann, U., Cattle, S.R., Minasny, B., McBratney, A.B., 2016. Utilizing portable $\mathrm{X}$-ray fluorescence spectrometry for in-field investigation of pedogenesis. Catena $139,220-231$.

Stolt, M.H., Baker, J.C., Simpson, T.W., 1993. Soil-landscape relationships in Virginia: I. Soil variability and parent material uniformity. Soil Sci. Soc. Am. J. 57, 414-421.

Stoner, M.G., Ugolini, F., 1988. Arctic pedogenesis: 2. Threshold-controlled subsurface leaching episodes. Soil Sci. 145, 46-51.

Tandarich, J.P., Darmody, R.G., Follmer, L.R., Johnson, D.L., 2002. Historical development of soil and weathering profile concepts from Europe to the United States of America. Soil Sci. Soc. Am. J. 66, 335-346.

Taylor, M.D., Lowe, D.J., Hardi, P., Smidt, G., Schnug, E., 2016. Comparing volcanic glass shards in unfertilised and fertilised Andisols derived from rhyolitic tephras, New Zealand: evidence for accelerated weathering and implications for land management. Geoderma 271, 91-98.

Ugolini, F., Dahlgren, R., Shoji, S., Ito, T., 1988. An example of andisolization and podzolization as revealed by soil solution studies, southern Kakkoda, northeastern Japan. Soil Sci. 145, 111-125.

Vazhenin, L.G., Dolgopolova, R.V., Snetkova, A.P., 1969. Microvariation of characteristics and properties of soils within a soil profile. Pochvovedeniye 4, 24-39 (In Russian).

Veenstra, J.J., Lee Burras, C., 2015. Soil profile transformation after 50 years of agricultural land use. Soil Sci. Soc. Am. J. 79, 1154-1162.

Wall, G.J., Marsh, M., 1988. Within-pedon variability of trace metals in southern Ontario. Can. J. Soil Sci. 68, 53-61.

Wang, Q.-B., Hartemink, A.E., Jiang, Z.-D., Jin, N.-X., Sun, Z.-X., 2017. Digital soil morphometrics of krotovinas in a deep Alfisol derived from loess in Shenyang, China. Geoderma 301, 11-18.

Waynick, D.D., 1918. Variability in soils and its significance to past and future soil investigations. I. A statistical study of nitrification in soils. vol. 3. University of California Publications in Agricultural Sciences, pp. 243-270. 
Waynick, D.D., Sharp, L.T., 1919. Variability in soils and its significance to past and future soil investigations. II. Variability in nitrogen and carbon in field soils and their relation to the accuracy of field trials. 3, University of California publications in agricultural sciences, pp. 121-139.

Webster, R., Lark, M., 2012. Field Sampling for Environmental Science and Management. Routledge.

Weindorf, D.C., Zhu, Y., Haggard, B., Lofton, J., Chakraborty, S., Bakr, N., Zhang, W., Weindorf, W.C., Legoria, M., 2012. Enhanced pedon horizonation using portable X-ray fluorescence spectrometry. Soil Sci. Soc. Am. J. 76, 522-531.

Wu, S., Wang, C., Liu, Y., Li, Y., Liu, J., Xu, A., Pan, K., Li, Y., Pan, X., 2018. Mapping the salt content in soil profiles using Vis-NIR hyperspectral imaging. Soil Sci. Soc. Am. J. 82, 1259-1269.

Zebarth, B.J., Rees, H., Walsh, J., Chow, L., Pennock, D.J., 2002. Soil variation within a hummocky podzolic landscape under intensive potato production. Geoderma 110, 19-33.

Zhang, Y., Hartemink, A.E., 2017. Sampling designs for soil organic carbon stock assessment of soil profiles. Geoderma 307, 220-230.

Zhang, Y., Hartemink, A.E., 2019a. Digital mapping of a soil profile. Eur. J. Soil Sci. $70,27-41$.

Zhang, Y., Hartemink, A.E., 2019b. A method for automated soil horizon delineation using digital images. Geoderma 343, 97-115.

Zhang, Y., Biswas, A., Adamchuk, V.I., 2017. Implementation of a sigmoid depth function to describe change of soil $\mathrm{pH}$ with depth. Geoderma 289, 1-10.

Zhang, Y., Hartemink, A.E., Huang, J., 2019. Quantifying coarse fragments in soil samples using a digital camera. Eurasian Soil Sci. 52, 954-962. 